\title{
Bibliography on HIV/AIDS in Ethiopia and Ethiopians in the Diaspora: The 2006 Update
}

\author{
Mesfin Samuel Mulatu ${ }^{1}$, Helmut Kloos ${ }^{2}$, Paul J. Converse ${ }^{3}$, and Damen Haile Mariam ${ }^{4}$
}

Introduction

This is the fourth update of the bibliography on HIV/AIDS in Ethiopia and Ethiopians in the Diaspora, which was originally published in this journal in 2003. That bibliography covered published and unpublished work on HIV/AIDS and related health conditions (e.g., other sexually transmitted infections, tuberculosis) for the period 1972 to 2002. Three subsequent updates were published in 2004, 2005 and 2006 respectively. The present update extends the bibliography to cover references not listed in previous updates and those recent publications or presentations that appeared in 2006.

As in the previous bibliographies, this update includes references to biomedical, epidemiological, clinical, psychosocial, socio-economic, cultural, behavioral, impact, intervention, and evaluation studies on HIV/AIDS and relevant research on sexually transmitted infections (STIs), tuberculosis, and other co-infections in Ethiopia and among Ethiopians in the Diaspora. Also included are studies dealing with sexual and contraceptive behaviors, and socio-cultural practices or conditions that increase the vulnerability of Ethiopians to HIV and associated opportunistic infections, including research on conditions of street and orphan children, sexual harassment and violence on women, and traditional practices (e.g., early marriage, female genital cutting) and their consequences.

The same strategies were used as in those previous bibliographies to identify and catalog the references. First, all new references that appeared in 2006 were searched in major databases, including MEDLINE, PsycLit, Sociological Abstracts, and POPLINE using the key words "Ethiopia and HIV," "Ethiopia and AIDS", "Ethiopia and reproductive health", and "Ethiopia and sexual behavior". As in the previous update, we also searched using "Ethiopia and Israel" to capture research on Ethiopian immigrants in Israel. Second, journals that were not indexed by these database systems (e.g., Ethiopian Journal of Health Development, Horn of Africa Journal of AIDS) were manually inspected for relevant references. Third, we searched for relevant presentations at the websites of major HIV/AIDS and public health conferences, including the $\mathrm{XVI}^{\text {th }}$ International Conference on AIDS (http://www.aids2006.org/), the $33^{\text {rd }}$ Annual International Conference on Global Health (http://www.globalhealth. org/conference_2006/), and the $14^{\text {th }}$ International Symposium on HIV and Emerging Infectious Diseases (http://www.isheid.com/prog2006.htm). $\quad$ Additional online searches were also made on website of major national or regional HIV/AIDS resource centers (e.g., http://www.etharc.org) and international organizations (e.g., http://www.unaids.org) for reports on HIV/AIDS in Ethiopia or Ethiopians in the Diaspora. Once all the 2006 references were selected and cataloged, similar searches for older references (particularly those published late in 2005) were made. Relevant references that were not listed in the previous bibliographies were retained and included in the present update.

This update includes 395 citations. Of these, 346 (87.6\%) appeared in 2006; 84 (21.3\%) are journal articles, 193 (48.9\%) conference abstracts, 98(24.8\%) masters theses or doctoral dissertation, 15 (3.8\%) reports, and 5 (1.3\%) book chapters. We have also updated our list of websites and included links to 12 websites with useful information and downloadable documents on HIV/AIDS in Ethiopia and Ethiopians in the Diaspora.

This year's update represents a significant increase in the number of references from the previous ones because of increases in conference presentations and graduate theses. There is a large increase in conference presentations from the last update, both proportionally to the total citations (from $7.2 \%$ to $48.9 \%$ ) and in absolute numbers (from 11 to 193). This change can be explained by our success in obtaining a more complete list of HIV/AIDS related presentations at major national (i.e., Ethiopian Public Health Association) and international conferences (i.e., International AIDS Conferences, International Conference on Global Health). For instance, this update lists conference abstracts that could not be listed in the past update (e.g., 2005 abstracts of the Ethiopian Public Health Association). The timing of some conferences (e.g., bi-annual occurrence of the International AIDS Conference) also contributed to the increase in the number of references in the current update. It is important to note, however, that there is also a trend towards increased presentations on HIV/AID issues on Ethiopia or among Ethiopians at international conferences. Figure 1A presents the number of abstracts containing "Ethiopia" presented in all of the 16 International AIDS Conferences. The figure shows a significant increase in number of abstracts during the last two meetings. In contrast, the number of published articles relating to HIV or AIDS and Ethiopia and archived in PubMed did not increase from 2005 to 2006 (see Figure 1B), even though citations concerning TB, but not schistosomiasis or malaria, did increase markedly from 2005 to 2006 (see Figure 2).

\footnotetext{
${ }^{1}$ Center for Community Prevention and Treatment Research, The MayaTech Corporation, Atlanta, Georgia 30324, USA; ${ }^{2}$ Department of Epidemiology and Biostatistics, University of California, Medical Center, San Francisco, San Francisco, CA 94143, USA; ${ }^{3}$ Center for Tuberculosis Research, Johns Hopkins University, School of Medicine, Baltimore, MD 21231, USA; ${ }^{4}$ Department of Community Health, Faculty of Medicine, Addis Ababa University, P.O. Box 32812, Addis Ababa, Ethiopia
} 


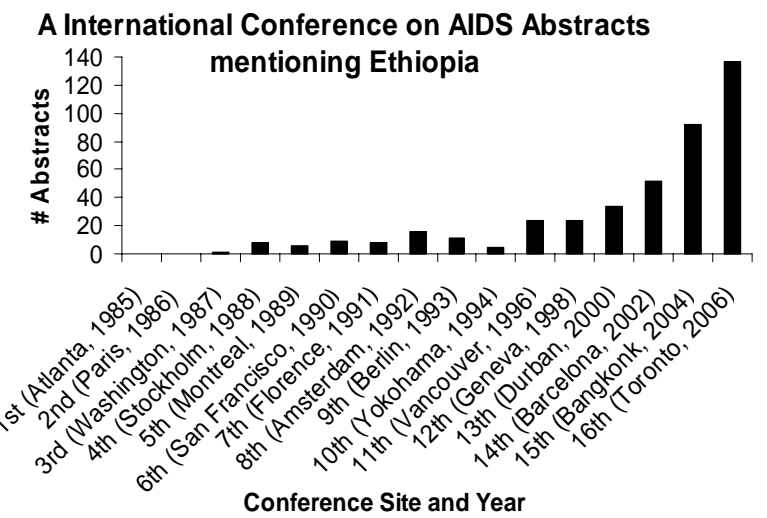

B PubMed References Citing HIV (or AIDS) and Ethiopia 1985-2006

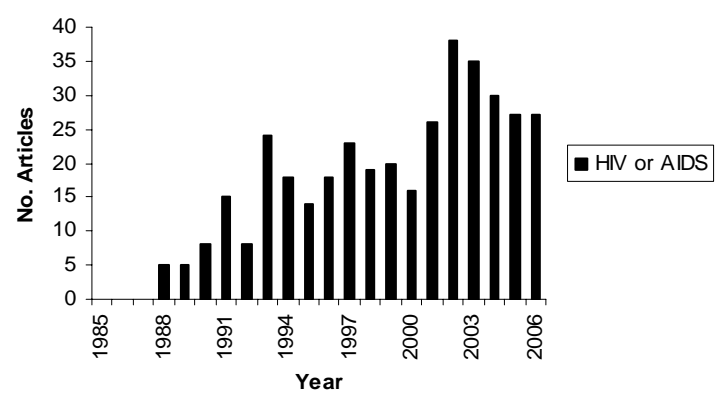

Figure 1: Presentations at the International Conference on AIDS (A) and Publications cited in PubMed (B) concerning Ethiopia and HIV or AIDS. The increase in presentations in recent years contrasts with a decline over the same period in material becoming full-length manuscripts

We are also witnessing an increase in graduate student research on HIV/AIDS at Addis Ababa University. There was a significant increase in the absolute number of theses from 50 in the last update to 98 in the present. As noted above, with the exception of one doctoral dissertation completed at a US-based university, all masters theses (M.A., M.P.H., and M.Sc.) listed were completed at various departments of Addis Ababa University. Once again, the Department of Community Health (Faculty of Medicine) produced the largest number of theses (24), followed by the School of Social Work (14), College of Education (13), Institute of Development Research (10), Department of Psychology (10), Demographic Training and Research Center (6), Department of Sociology and Social Anthropology (4), Department of Statistics (3), School of Journalism and Communication (3), Institute of Local and Regional
Development (3), Department of Microbiology, Immunology, and Parasitology (2), and one thesis each by the departments of Economics, Literature, Political Science and International Relations, Information Sciences, and Institute of Language Studies. This increase in the number of graduate theses may be attributable partly to our access to a more complete list of theses, and partly to the development of some new academic programs at Addis Ababa University that provided opportunities to their graduate students to study HIV/AIDS related social issues. The School of Social Work and the School of Journalism and Communication are examples of this growth. In contrast to past updates in which no thesis work from these schools could be included, this update lists 14 relevant master theses from the School of Social Work and 3 from the School of Journalism and Communication.

\section{PubMed References citing Ethiopia}

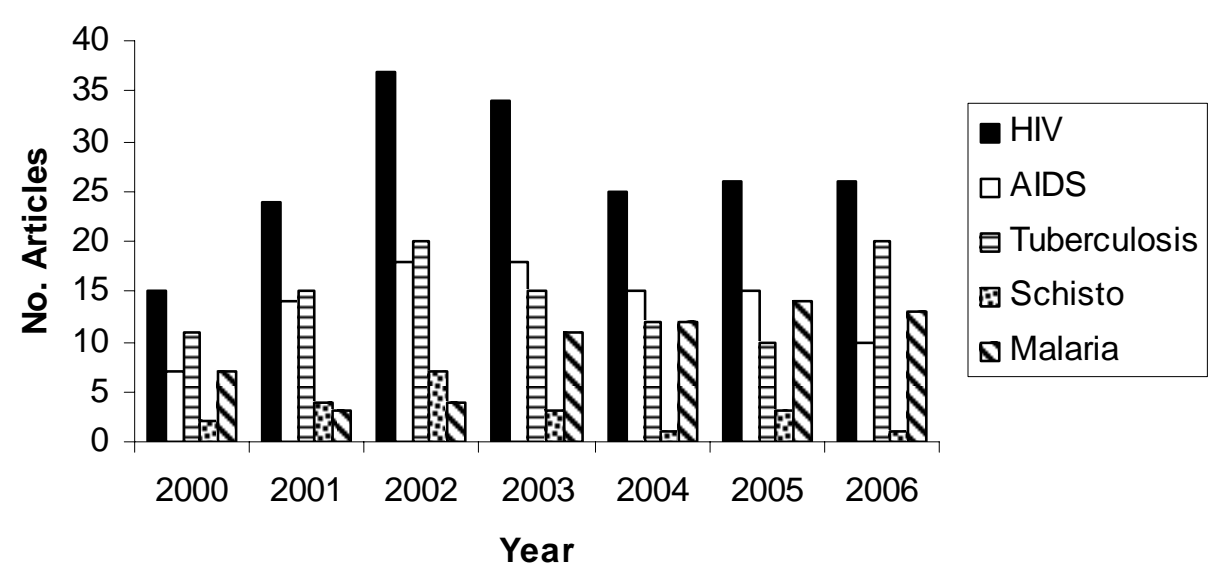

Figure 2: PubMed citations related to Ethiopia and HIV or selected infectious diseases. Although tuberculosis publications doubled from 2005 to 2006, other diseases saw no change or a decline 


\section{Basic Biomedical Research}

Only 19 (4.8\%) of the 395 references located dealt with research on basic biomedical issues. Of these, 8 (42.1\%) were journal articles and 16 (84.2\%) appeared in 2006. The most common research topics covered continued to be immune response to infection, diagnostic techniques or detection procedures, drug resistance and sensitivity of opportunistic pathogens including $\mathrm{M}$. tuberculosis, parasites, and STIs, and genetic composition and variability as well as molecular diagnostics of HIV. In this section, we also noted four studies conducted in China, Spain, and the United States that documented genetic variability and the rapid spread of the HIV-1 subtype C, a strain originally found in Ethiopia, to other parts of the world.

A significant gap still remains in a variety of biomedical research areas. With increasing antiretroviral therapy programs, it will become increasingly critical to monitor and study the nature and patterns of drug resistance, drug interactions, and responses to drugs among Ethiopian patients receiving treatment. In addition, with malaria, tuberculosis, hepatitis, and other diseases being highly prevalent in Ethiopia, basic laboratory research on the interaction and synergism of pathogens would help contribute significantly to our understanding of disease processes. While it is recognized that basic biomedical research is expensive and requires well-developed laboratory facilities and manpower, it is important that researchers and graduate students be encouraged to study HIV/AIDS related biomedical topics. None of the theses listed in this update was in basic biomedical research. We have not seen any significant increase in basic biomedical research over the last two or three updates, and hope that the research programs that existed at ENARP are being carried out by scientists in other laboratories.

\section{Epidemiological, Risk Factors, and Determinants Research}

This section contains 139 (35.2\%) references, making it the largest section as in previous updates. Twenty-nine (20.9\%) of these are journal articles and the rest are reports, conference abstracts, and theses, and 119 (85.6\%) of them appeared in 2006.

As might be expected from previous updates, the bulk of epidemiological research focuses on prevalence and correlates of sexual risk and protective behaviors. Several studies described the patterns and correlates of sexual risk behaviors among a variety of populations, including out-of-school youth, high school and college students, military, and the general public. Our attention was caught by a study that assessed the sexual risk behaviors of men who have sex with other men, a subpopulation that, to our knowledge, has not been studied previously in Ethiopia, unlike in other sub-Saharan African countries.
Knowledge and attitude surveys have also continued to dominate research in this area, although not as much as in previous updates. Researchers have examined knowledge, attitudes, and/or perceptions about HIV/AID, reproductive health and contraceptive methods, TB control, anti-retroviral therapy, home-based care, voluntary testing and counseling, and mother-to-child transmission prevention.

Studies on access, patterns of use and correlates of reproductive health services (e.g., family planning) and specific services aimed at reducing the spread of HIV/AIDS (e.g., condom promotion, VCT, PMTCT) have also attracted a sizeable number of researchers. We identified several studies that addressed the extent of unmet needs, intentions, and current use of contraceptives and the psychosocial and socio-economic determinants of intent or use of contraceptives or reproductive health services broadly defined. It is interesting to note that most of these studies were conducted among young women, and appeared to ignore the important role of men in reproductive health.

A significant amount of research on VCT is accumulating. There are studies addressing the levels of intention or willingness to use or current use of VCT services and the psychosocial correlates and barriers of intentions or current use of VCT services among a variety of populations in both urban and rural settings throughout the country. We found only one study that addressed the determinants of PMTCT use and two studies focusing on breast-feeding intentions or practices among HIV infected women. Condom use and its determinants or barriers were also addressed, although not as much as one might expect given its ubiquitous promotion as a primary prevention tool.

Two themes of research on issues that particularly affect young girls and women emerged in this update. The first focuses on the prevalence, correlates, and consequences of sexual and domestic abuse among girls and women. The second line of research focuses on the social, cultural, economic, and political factors that put girls and women in vulnerable positions. Some of the most important topics under this theme include effects of gender stereotypes, commercial sex, widow inheritance, and barriers to female participation in prevention programs. Given the paucity of gender disaggregated information, we recommend further studies on issues that affect girls and women.

Serological surveys and estimates have also been highlighted in a reasonable number of reports and presentations. A few government and international reports provided national prevalence estimates of HIV/AIDS in Ethiopia or in specific settings such as rural Ethiopia. We have also found citations that addressed seroprevalence of HIV among specific populations such

Ethiop.J.Health Dev. 2007;21(1) 
as blood donors and factory workers. Other serological studies focused on rates of co-infection of HIV with TB, leprosy, visceral leishmaniasis, and intestinal parasites. Still other studies focused on prevalence of other viral STDs, including HPV, or tuberculosis regardless of HIV status.

Three emerging epidemiological research themes need mention here. The first is the study of the relationships between substance abuse and the HIV epidemic in Ethiopia. We found three studies that linked problem drinking and khat chewing to HIV risk behaviors. This area is still understudied, and we recommend further research on the contribution of substance abuse to risk behaviors, immune suppression, and adherence to HIV treatment, and other clinical and non-clinical health outcomes. The second emerging research theme is injection safety, occupational exposure, and other iatrogenic issues relevant to HIV. Five references were found that addressed such issues as injection safety, blood transfusion risk, needle stick injuries, and occupational exposure to blood, bodily fluids, and HIV. These types of studies are critical to ensuring the safety of the public and the health workers from accidental exposure to HIV and other pathogens. A third emerging research area is the link between HIV/AIDS and food security, which has been addressed in two references. The reciprocal relationships between HIV and food security are particularly relevant to the situation in Ethiopia, where widespread acute and chronic food shortages and malnutrition must be expected to play a significant role in the pathogenesis of HIV/AIDS.

Overall, epidemiological and related research on HIV/AIDS continues to be multifaceted. However, the studies remain predominantly descriptive in nature and primarily target women, youth, orphan and street children, and people living with HIV/AIDS. In addition, these studies are still predominantly urban based, although there are signs that research with rural populations is increasing. Studies involving diverse geographic, socioeconomic, and cultural populations need to be encouraged toward a better understanding of the epidemiology of HIV/AIDS and its risk factors nationwide.

\section{Clinical Research}

A total of 35 (8.9\%) references deal with issues involving HIV/AIDS patients within a clinical setting. Of these, 10 (28.6\%) were journal articles, and 29 (82.9\%) were published or presented at conferences in 2006.

As in previous updates, most clinically oriented research focused on describing the clinical characteristics, immune responses, or effects on disease outcome of coinfections of HIV with other sexually transmitted diseases, tuberculosis, malaria, helminthes, or other intestinal infections, with a preponderance of studies on effects of intestinal infections. Given the high prevalence of these infections, the effort towards understanding their role in increasing individuals' vulnerability to HIV infection or to contributing to poorer outcomes among HIV infected people continues to be critical. A second important line of clinical research has been the study of the clinical characteristics, immune response, and disease outcome of HIV/AIDS patients receiving antiretroviral therapy (ART). In four studies, the effects of ART on patient immune response and/or survival or death have been investigated. We found only one study tackling the issue of adherence to ART. Interestingly, two citations by the same author have looked at the quality of life of people taking ART. Finally, there were studies that generally focused on some clinical parameters of HIV/AIDS patients, diagnostic issues as well as citations on disease management approaches or treatment guidelines.

Several clinical issues remain understudied in view of the rapidly increasing coverage of ART. As a critical element of the treatment process, it is important that levels and determinants of adherence or compliance with therapy (ART or therapy for opportunistic infections) be further investigated. There are also gaps in ART related research. As the number of HIV/AIDS patients receiving ART increases, we expect an increased need to understand and manage such issues as drug resistance, drug interactions, and adverse reactions and complications to ART (e.g., lipodystrophy, metabolic abnormalities, mitochondrial toxicity, and lactic acidosis). Furthermore, given that a majority of HIV/AIDS patients do not have access to ART, it is also very important that the nature and effects of other forms of treatment are examined. These include the effects of nutritional supplements, treatment for other infections (e.g., STDs, hepatitis, malaria, tuberculosis), and traditional medicines on health outcomes of HIV/AIDS patients.

\section{Impact Research}

Twenty-seven (6.8\%) of the references deal with research on the impacts of the HIV/AIDS epidemic in Ethiopia. Of these, only 5 (18.5\%) were published articles and 21 (88.9\%) appeared in 2006.

Four interrelated lines of research characterize the study of the impacts of the HIV/AIDS epidemic in Ethiopia. First, several citations covered research on the magnitude, needs, and living situation of HIV/AIDS orphans or the psychosocial, developmental, educational, or behavioral impacts and challenges of being orphaned by HIV/AIDS. Second, researchers also focused on the psychosocial well-being or distress among people infected by HIV/AIDS and/or their close family members. Third, the socio-economic impact of HIV/AIDS was also investigated, as it affects the traditional social support network systems of the elderly, 
income at the household level, productivity at a company level, and economic development at the national level. Finally, a few studies addressed the demographic impact of the epidemic, often in relation to mortality.

The potential impacts of the HIV/AIDS epidemic in Ethiopia are not yet fully studied.For example, we still need information on the broader impact of the epidemic on the traditional social safety nets and support networks, including impacts on the immediate family, extended family, and self-help associations. Research on the patterns of coping behavior and the burden of care giving to incapacitated AIDS patients may yield valuable information for strengthening care and support programs and services. Impacts of the epidemic on the education and healthcare sectors need closer examination. Given that the country is predominantly rural, the impact on the epidemic on food security and other agriculture and other rural-based economic and social activities may require urgent attention.

\section{Intervention Research}

A research area that rapidly expanded within the last two years is intervention research. With 104 (26.3\%) references, this section contains the second largest number of references in this update. Of these only 13 $(12.5 \%)$ are journal articles and 94 (90.4\%) appeared in 2006.

Several intervention approaches have been studied. As expected, much of the research covers the initiation, expansion, challenges, and successes of HIV treatment, particularly antiretroviral therapy. Some of these studies assessed approaches to address barriers to scaling up current levels of ART, to increase adherence, and to integrate ART services to other health services. Related to ART, a limited number of intervention studies have addressed efforts to increase awareness, access, and acceptance of VCT and PMTCT services.

A few citations dealt with behavioral change public education interventions aimed at reducing risk behaviors or stigma or increasing awareness about HIV/AIDS or preventive services. Some of these communication strategies involved mass media and school anti-AIDS clubs.

A large number of studies examined the social and community responses to the HIV/AIDS epidemic. The most studied of these approaches is home- and community-based care and support interventions. Efforts to provide and scale up home-based care for HIV/AIDS patients, orphans, or vulnerable children are documented in several citations. Several other studies examined strategies to expanding community based care and support services. One such strategy appears to be improving partnerships between community-based, faithbased, and governmental organizations working in the field. Another expanding approach is improving the involvement of members of the community. Several citations addressed efforts at increasing the role of young people, community- and faith-based organizations, and private businesses, in HIV/AIDS prevention, care and support of patients and orphans, or dealing with other impacts of the epidemic.

Improving the capacity of the healthcare system was also addressed in a few of the references. Efforts towards healthcare work force development and re-training, scaling up services, developing training tools, making the work environment safer, and injection safety have been identified.

Several citations focused on global, cross-national, and political responses to the HIV/AIDS epidemic in Ethiopia. The activities, challenges, and effects of donor and aid programs, such as the Clinton Foundation, the US President's Emergency Plan for AIDS Relief and the Global Fund to Fight against AIDS, Tuberculosis, and Malaria have been highlighted in several citations. There were also some references that addressed the need to create structures for increased donor-to-donor coordination, increased political and government programming, and increased need to address human rights.

A limited number of studies concentrated on newer intervention approaches to prevent HIV/AIDS or mitigate its impacts such as improving women's income and promoting gender rights. Another relatively new approach to reducing the chances of infection is male circumcision. Recent intervention trials in South Africa, Uganda, and Kenya have shown a $50 \%$ or better protection for circumcised men compared to those not circumcised - making it a promising candidate as one of the tools for curbing the spread of HIV (see Williams et al. 2006 ref. 99 in this section). Given that there are regional and cultural group differences in the practice of male circumcision in Ethiopia, this issue demands epidemiological research as well as targeted culturally sensitive interventions. At the very least, one would want to know if men in areas where circumcision is almost universal (e.g., Amhara or Tigray Regions) have a lower likelihood of HIV or other STIs than men in areas where this practice is not as common (e.g., Gambella or Benishangul-Gumuz), controlling for risk factors. Preliminary survey data indicate that this may be the case (Tables 13.1.2 and 14.8 in ref. 33 in Section 3. Epidemiological, Risk Factors, and Determinants Research) with $>2$-fold benefit of male circumcision. Williams et al. estimate that there would be a reduction of over 20,000 HIV infections per year overall in Ethiopia. Should the advantages of circumcision found elsewhere be replicated, it would represent one weapon in the fight against the spread of the epidemic in Ethiopia as well. It would also be important for the population to 
understand and act with the knowledge that the protection is only partial, that the surgery must be performed skillfully, and that complete healing would be critical before the resumption of sexual activity.

\section{Monitoring and Evaluation Research}

Fifty $(12.7 \%)$ of the references listed in this update examine HIV/AIDS related monitoring and evaluation activities. Of these, 8 (16.0\%) are published articles and $46(92.0 \%)$ appeared in 2006. This year's update contains a sizable increase in the number of citations suggesting that research in this area is picking up, apparently because of the increasing need to provide evidence of accountability and effectiveness of projects and programs.

We noted several evaluation studies that examined the cultural appropriateness, content coverage, patterns of use, and effects of mass media aimed at increasing awareness about HIV/AIDS, reducing stigma, or encouraging the use of preventive or palliative services. Among the evaluated media programs are radio advertisements or drama, television campaigns, music videos, newspaper coverage, and telephone help line.

A few studies have also examined strategies and systems to monitor the epidemic, particularly through the use of behavioral and serological surveillance systems, by mining utilization records of VCT and ART services, and by case finding outreach programs for tuberculosis.

Many citations focused on process and outcome evaluation of specific projects or programs. Among topics covered include evaluation of the process by which program or project components were applied, such as the degree to which principles of counseling or appropriate counseling tools were applied in VCT or infant feeding centers. Others examined the quality or adequacy of services provided by VCT centers or antiAIDS clubs. Still others assessed the overall experiences, challenges, and opportunities in implementing programs, including community-based care and support, treatment and control, prevention, and training and capacity development programs.

While the growing interest in evaluation of communication efforts is encouraging (along with the maturation of the new School of Journalism and Communication), there remains a gap in knowledge about the effects of other HIV/AIDS communication efforts. For instance, what are the patterns and effects of parent-child or faith leader-follower communication regarding HIV/AIDS or risk and preventive behaviors? We found only two references on economic evaluation of interventions. In addition, effectiveness studies that causally link specific intervention activities to specific changes in health behavior or health outcome are few. The greater pursuit of these areas may bear fruit for designing and implementing appropriate and costeffective interventions.

Research on HIV/AIDS in Ethiopians in the Diaspora We located 21 (5.3\%) references that deal with HIV/AIDS and related issues among Ethiopians in the Diaspora. Of these, 10 (47.6\%) were journal articles, and 18 (85.7\%) were published or presented at conferences in 2006. These citations continue to come predominantly from Israel and North America.

Four references addressed the potential or existing efforts of the Ethiopian Diaspora to get involved in HIV/AIDS interventions or capacity development in Ethiopia. Israeli studies tend to focus on prevalence of tuberculosis infections among children and adolescents of Ethiopian immigrants, mother-to-child transmission of HIV, immune responses and other clinical profile of patients receiving treatment. Five Canadian studies presented findings on perceptions of risk, risk behaviors, attitudes about the origins and prevention of HIV/AIDS, and the changing demographic profile of HIV infection among Ethiopian and other immigrants in Toronto. Two other citations described the involvement of American academics/physicians in HIV/AIDS non-profit organizations working in Ethiopia (e.g., People to People, Inc.). Two additional studies addressed the prevention needs and HIV/AIDS related mortality among Ethiopian and other refugees in Botswana and Somaliland.

The patterns of HIV infection, risk and protective behaviors, and clinical features and treatment outcomes among Ethiopians in the Diaspora are largely unknown. This is particularly true among Ethiopian immigrants in Europe and North America, and the large number of Ethiopian refugees in other parts of Africa (including those in Kenya, Sudan, South Africa) and the Middle East. As we indicated in previous updates, this may be due to the scattered distribution of the immigrants/refugees, their lack of access to or their inaccessibility by researchers and service providers, and their classification together with other immigrants/ refugees and citizens of African origin, as in most US national health surveys. With growing movement of Ethiopians outside of their country, we expect greater need to understand and address their particular public health risks, needs, and resources. We repeat our previous call for further research on these issues among Ethiopians in the Diaspora.

\section{Conclusion}

Although the distribution of references follows previous bibliographies, this year's update represents a significant increase in the number of references from the last update. As expected, there appears to be a trend towards increased research activity in intervention research and in monitoring and evaluation research. Real increases in research activity may be related to expansion of some 
programs (e.g., ART, VCT, PMTCT) and perhaps growth in graduate programs and relevant research at Addis Ababa University. Research still remains urban-based, although we have noted increased research with rural populations. Despite further expansion of ART programs, research on adherence and adverse effects are woefully inadequate. We are concerned that public education and condom promotion programs did not feature as significantly as before, perhaps reflecting the diversion of resources or attention to HIV treatment or palliative care. There is also room to expand monitoring and evaluation research by expanding data collection systems (e.g., seroprevalence and behavioral surveillance) and incorporating economic evaluation approaches.

In this update, we have been unable to include relevant articles from two other health related publications in Ethiopia (i.e., Ethiopian Journal of Health Sciences and Ethiopian Journal of General Medical Practice) and graduate level theses from Ethiopian universities other than Addis Ababa University. We hope to include references from these sources in future updates. We would also welcome and be grateful for any corrections and suggestions readers may have for future updates of the bibliography.

\section{Section 1. Earlier Bibliographies on HIV/AIDS and Related Sociocultural and Economic Issues}

1. Alemayehu E, Belachew T. Health science student research at Jimma University: Abstracts of all public health faculty graduate student research projects (19962004). Addis Ababa: Addis Ababa University Press, 2005.

2. Alemayehu E, Belachew T. Health science student research at Jimma University: Abstracts of all medical sciences faculty graduate student research projects (19912004). Addis Ababa: Addis Ababa University Press, 2005.

3. Berhane Y, Hailemariam D, Kloos H. (Eds). Epidemiology and ecology of health and disease in Ethiopia. Addis Ababa, Ethiopia: Shama Books; 2005.

4. Center for Research Training and Information on Women in Development (CERTWID). An annotated bibliography of gender issues in Ethiopia. Vol. 1 \& 2. CERTWID, Addis Ababa University, 2004.

5. Converse PJ, Wuhib T, Mulatu MS, Kloos H. Bibliography on HIV/AIDS in Ethiopia and Ethiopians in the Diaspora. Ethiop J Health Dev 2003;17(Special Issue):33-85.

6. Converse PJ, Mulatu MS, Kloos H, Haile Mariam D, Wuhib T, Pankhurst A. Bibliography on HIV/AIDS in Ethiopia and Ethiopians in the Diaspora: The 2005 update. Ethiop J Health Dev 2006;20(1):60-70.

7. Ethiopian Public Health Association (EPHA). Extracts of MPH theses works by EPHA-sponsored graduate students in public health. EPHA, Addis Ababa, 2004.

8. Kloos H, Mulatu MS, Converse PJ. Bibliography on HIV/AIDS in Ethiopia and Ethiopians in the Diaspora: 2003 Update. Ethiop J Health Dev 2004;18(1):57-64.

9. Mulatu MS, Kloos H, Converse PJ, Wuhib T, Pankhurst A. Bibliography on HIV/AIDS in Ethiopia and Ethiopians in the Diaspora: The 2004 update. Ethiop J Health Dev 2005;19(1):64-85.

\section{Section 2. Basic Biomedical Research}

This section covers laboratory-based biomedical research, including studies on HIV structure, replication, and host

immune responses; co-infection with other agents; development and testing of laboratory procedures; and other related laboratory studies.

1. Andualem B, Kassu A, Diro E, Moges F, Gedefaw M. The prevalence and antimicrobial responses of Shigella Isolates in HIV1 infected and uninfected adult diarrhoea patients in north west Ethiopia. Ethiop J Health Dev. 2006;20(2):99105.

2. Asmamaw D, Seyoum B, Atsabiha H, Woldemeskel D, Addus H, Yamuah LK, et al. Drug susceptibility patterns of M. tuberculosis isolates in Addis Ababa. Abstracts of the XVIth Annual Conference of the Ethiopian Public Health Association; Addis Ababa, Ethiopia; 2005. Poster presentation no. 4.

3. Collins M, Hurford R, Chao Y, Christina Patrick, Langford TD. Variability in virus and in host during HIV1 infection. Horn Africa J AIDS 2006;3(2):38-46.

4. Demissie A, Leyten EM, Abebe M, Wassie L, Aseffa A, Abate G, et al. Recognition of stage-specific mycobacterial antigens differentiates between acute and latent infections with Mycobacterium tuberculosis. Clin Vaccine Immunol 2006;13(2):179-86.

5. Demissie A, Wassie L, Abebe M, Aseffa A, Rook G, Zumla A, et al. The 6-kilodalton early secreted antigenic target-responsive, asymptomatic contacts of tuberculosis patients express elevated levels of interleukin-4 and reduced levels of gamma interferon. Infect Immun 2006;74(5):2817-22.

6. Gottesman BS, Grossman Z, Lorber M, Levi I, Shitrit P, Katzir M, et al. Comparative performance of the Amplicor HIV-1 Monitor Assay versus NucliSens EasyQ in HIV subtype C-infected patients. J Med Virol 2006;78(7):883887.

7. Kassa D, Adane A, Tessema D, Tamene W, Melese H, Ahemedin Z, et al. Comparisons of ELISA and Sample Rapid Test (SRTs) for HIV-1 testing in Ethiopia. Abstracts of the XVIIth Annual Conference of the Ethiopian Public Health Association; Harar, Ethiopia; 2006. Abstract no. 80.

8. Kassa D, Tessema D, Melese H, Messele T, Tamene W, Ahmedin Z, et al. Evaluation of dried blood spots (DBS) for HIV-1 antibody testing in Ethiopia. Abstracts of the XVI International AIDS Conference; Toronto, Canada; 2006. Abstract no. MOPE0150.

9. Leng Q, Bentwich Z, Borkow G. Increased TGF-beta, Cbl$\mathrm{b}$ and CTLA-4 levels and immunosuppression in association with chronic immune activation. Int Immunol 2006;18(5):637-644.

10. Mihret A, Mamo G, Tafesse M, Hailu A, Parida SK. Role of dendritic cells in the initiation of immunity to Mycobacterium tuberculosis infection. Abstracts of the XVIth Annual Conference of the Ethiopian Public Health Association; Addis Ababa, Ethiopia; 2005. Poster presentation no. 3 .

11. Oliveira TD, Cassol SA, Iversen A, Andrew R. A phylogenetic study of the origins, adaptive evolution and global expansion of HIV-1 subtype C. Abstracts of the XVI International AIDS Conference; Toronto, Canada; 
2006. Abstract no. CDA0106.

12. Schon T, Wolday D, Elias D, Melese E, Moges F, Tessema $\mathrm{T}$, et al. Kinetics of sedimentation rate, viral load and TNF-alpha in relation to HIV co-infection in tuberculosis. Trans $\mathrm{R}$ Soc Trop Med Hyg 2006;100(5):483-488.

13. Seyoum B, Asmamaw D, Iwnetu R, Yamuah LK, Woldeamanuel Y, Assefa A. Characterization of mycobacterial isolates from lymph nodes of patients with tuberculous lymphadenitis in Derra Woreda, North Shewa, Ethiopia. Abstracts of the XVIth Annual Conference of the Ethiopian Public Health Association; Addis Ababa, Ethiopia; 2005. Oral presentation no. 7.

14. Seyoum E, Wolday D, Girma M, Malmsten A, Meselle T, Gronowitz JS, et al. Reverse transcriptase activity for quantitation of HIV-1 subtype $\mathrm{C}$ in plasma: Relation to RNA copy number and CD4 T-cell count. J Med Virol 2006;78(2):161-168.

15. Tegbaru B, Asmare Y, Westerlaken M, Nanlohy NM, Vrisekoop N, Miedema F, et al. Tuberculosis in HIV infection at lower CD4+ $\mathrm{T}$ cell count: A consequence or a cause for immune activation. Abstracts of the XVIIth Annual Conference of the Ethiopian Public Health Association; Harar, Ethiopia; 2006. Abstract no. 28.

16. Thomson M, Casado MG, Sierra M, Delagado E, Muñoz $\mathrm{M}$, Vega $\mathrm{Y}$, et al. Characterization of near full-length genome HIV-1 subtype C sequences from Spain, with evidence of intrasubtype recombination. Abstracts of the XVI International AIDS Conference; Toronto, Canada; 2006. Abstract no. CDA0091.

17. Tegbaru B, Klien M, Wolday D, Girma M, Vrisekoop N, Hailu E, et al. Increased percentage of regulatory $\mathrm{T}$ cells is associated with advanced HIV disease: antigen driven induction. Abstracts of the XVIIth Annual Conference of the Ethiopian Public Health Association; Harar, Ethiopia; 2006. Abstract no. 29.

18. White EJ, McColgan B, Katzenstein D. A comparison of coreceptor prediction programs for subtype C HIV-1. Abstracts of the XVI International AIDS Conference; Toronto, Canada; 2006. Abstract no. WEPE0034.

19. Zhang J, Fu J, Yang P, Xu A. Molecular epidemiology of HIV-1 strains circulating in Shandong, China. Abstracts of the XVI International AIDS Conference; Toronto, Canada; 2006. Abstract no. CDC0081.

\section{Section 3. Epidemiological, Risk Factors, and Determinants Research}

This section includes studies on the epidemiology of HIV and other opportunistic infections, AIDS and related diseases, and risk and protective behaviors. It also covers research on the biological, psychosocial, socioeconomic, cultural, structural, and other contextual determinants of HIV transmission and prevention.

1. Abachebsi TW. Socioeconomic and demographic correlates of commercial sex work in Addis Ababa. Unpublished MA Thesis, Institute of Development Research, Addis Ababa University; 2006.

2. Abashawl A, Ahmed AI, Bedri A, Mengistu Y, Omer S, Kumbi S, et al. Breastfeeding practices by HIV status in Addis Ababa, Ethiopia. Abstracts of the XVI International AIDS Conference; Toronto, Canada; 2006. Abstract no. WEPE0335.

3. Abebe MG. A study on contributing factors to adolescents' reproductive behavior in slum areas of Addis Ababa: The case of Teklehaimanot area. Unpublished MA Thesis, School of Social Work, Addis Ababa University; 2006.

4. Abebe TA. Knowledge, attitude and behavior of female youth on HIV/AIDS in Nazareth (Adama Town). Unpublished MA Thesis, Institute of Development Research, Addis Ababa University; 2006.

5. Abreham HT. Determining factors that affect pregnant women's utilization of PMTCT services: The case of health facilities at Nazareth/Adama. Unpublished MA Thesis, School of Social Work, Addis Ababa University; 2006.

6. Adamu R, Hassen E, Abashawl A, Ahmed AI, Solomon K, Ruff A, et al. Reasons for refusal to participate in a PMTCT trial. Abstracts of the XVI International AIDS Conference; Toronto, Canada; 2006. Abstract no. CDD0022.

7. Addissie A, Daba S, Girma M, Tegene Y, Lea M. Role of women in decision making for contraceptive utilization in Awassa Town. Abstracts of the XVIIth Annual Conference of the Ethiopian Public Health Association; Harar, Ethiopia; 2006. Abstract no. 17.

8. Admasu LA. Knowledge and attitude of people towards VCT for HIV: The case of Shashemene. Unpublished MA thesis, College of Education, Addis Ababa University, 2006.

9. Admassu M, Fitaw Y. Factors affecting acceptance of VCT among different professional groups in north and south Gondar administrative zones. Abstracts of the XVIth Annual Conference of the Ethiopian Public Health Association; Addis Ababa, Ethiopia; 2005. Poster presentation no. 12.

10. Admassu M, Fitaw Y. Factors affecting acceptance of VCT among different professional and community groups in North and South Gondar Administrative zones, north west Ethiopia. Ethiop J Health Dev. 2006;20(1):24-31.

11. Adole MW. Correlates of intention to use family planning among women of reproductive age in Oromiya Region. Unpublished MA Thesis, Institute of Development Research, Addis Ababa University; 2006.

12. Agonafir AM. Perceived barriers to undergo voluntary HIV counseling and testing among Bahir Dar University students. Unpublished MA Thesis, Department of Psychology, Addis Ababa University; 2006.

13. Ahmed MM. Sexual abuse of girls with disabilities: A case of four girls in Addis Ababa. Unpublished MA Thesis, Department of Psychology, Addis Ababa University; 2006.

14. Aklilu SB. Knowledge, attitude and practice of voluntary counseling and testing among college students in Addis Ababa. Unpublished MA Thesis, Institute of Development Research, Addis Ababa University; 2006.

15. Alem A, Kebede D, Mitike G, Enqusellase F, Lemma W. Unprotected sex, sexually transmitted infections and problem drinking among female sex workers in Ethiopia. Ethiop J Health Dev. 2006;20(2):93-98.

16. Alemayehu WA. Socio-demographic and behavioral determinants of sero-discordance among couples taking HIV test, Dessie, Ethiopia. Unpublished MPH Thesis, Department of Community Health, Addis Ababa University; 2006.

17. Amerga RT. Sexual violence and reproductive health among school adolescents in Addis Ababa. Unpublished MA Thesis, Institute of Development Research, Addis Ababa University; 2006.

Ethiop.J.Health Dev. 2007;21(1) 
18. Aregawi AA. Perception of high school students toward VCT, based on the health belief model in Butajira, SNNPR. Unpublished MPH Thesis, Department of Community Health, Addis Ababa University; 2006.

19. Ashenafi S. Women and young girls: The new face of HIV and AIDS. Horn Africa J AIDS 2006;3(2):16-19.

20. Assegid M, Tesfaye F. Assessment of intention and practice of VCT and infant feeding in the context of HIV/AIDS among lactating mothers in Harar Town. Abstracts of the XVIIth Annual Conference of the Ethiopian Public Health Association; Harar, Ethiopia; 2006. Abstract no. 41.

21. Assen IY. Comparative study of knowledge, attitude and benefit about HIV/AIDS and voluntary counseling and testing (VCT) among Defense University students who identified their HIV negative status and those who do not. Unpublished MA thesis, College of Education, Addis Ababa University, 2006.

22. Atsbeha H. Seroepidemiological survey of viral STDs in rural Ethiopia: A population based comparative study on the prevalence of HIV-1, HSV-2, and HBV in Gundo Meskel and Shebe Towns, Ethiopia. Unpublished MPH Thesis, Department of Microbiology, Immunology, and Parasitology, Addis Ababa University; 2006.

23. Atsbeha H, Assefa A, Worku A, Asmamaw D, Iwnetu R, Yamuah LK, et al. Seroepedemic survey of viral STDs in rural Ethiopia: A population-based comparative study on the prevalence of HIV, HSV-2 and HBV in Gundomekel and Shebe, Ethiopia. Abstracts of the XVIth Annual Conference of the Ethiopian Public Health Association; Addis Ababa, Ethiopia; 2005. Poster presentation no. 6.

24. Bedada TE. Correlates of contraceptive use and method of choice in urban Ethiopia. Unpublished MA Thesis, Demographic Training and Research Center, Addis Ababa University; 2006.

25. Bedri A, Adamu Y, Abashawl A, Gudetta B, Ahmed AI, Adamu R, et al. Occupational exposure to HIV and PEP experience in a tertiary medical center in Ethiopia. Abstracts of the XVI International AIDS Conference; Toronto, Canada; 2006. Abstract no. CDC0641.

26. Belayneh TB. Factors affecting access to and utilization of reproductive health services among women of Dawro Zone, SNNPR. Unpublished MA Thesis, Institute of Development Research, Addis Ababa University; 2006.

27. Berhane Y. Impact of injection safety: Epidemiological evidences. Abstracts of the XVIth Annual Conference of the Ethiopian Public Health Association; Addis Ababa, Ethiopia; 2005. No abstract no.

28. Berhane Y, Wuhib T, Sanders E, Lulseged S, Ismail S, Melaku Z, et al. HIV/AIDS. In Berhane Y, Hailemariam $\mathrm{D}$, Kloos $\mathrm{H}$, editors. The Epidemiology and Ecology of Health and Disease in Ethiopia. 3rd ed. Addis Ababa, Ethiopia: Shama Books; 2006: p. 446-474.

29. Bishop-Sambrook C, Alemayehu N, Assegid Y, Woldewahid G, Gebremedhin B. The rural HIV/AIDS epidemic in Ethiopia and its implications for market-led agricultural development. In: Bishop-Sambrook C, editor. AIDS, Poverty, and Hunger: Challenges and Responses. Highlights of the International Conference on HIV/AIDS and Food and Nutrition Security, Durban, South Africa, 14-16 April, 2005. Washington: International Food Policy Research Institute; 2006: p. 245.

30. Bizuneh AA. Assessment of sexual behavior related to HIV/AIDS in a community practicing widow inheritance in Digalu Tijo, Arsi Zone, Oromiya Regional State. Unpublished MPH Thesis, Department of Community Health, Addis Ababa University; 2006.

31. Bradley H, Bedada A, Brahmbhatt H, Kidanu A, Gillespie D, Tsui A. Educational attainment and HIV status among Ethiopian voluntary counseling and testing clients. AIDS Behav 2006; Nov 2: no page number [electronic publication].

32. Canivet C. [Clean women in shawls give us hope...]. Läkartidningen 2006;103(38): 2762.

33. Central Statistical Agency and ORC-Macro. Ethiopia Demographic and Health Survey 2005. Addis Ababa and Calverton, Maryland: Central Statistical Agency and ORCMacro; 2006.

34. Cruz I, Nieto J, Moreno J, Canavate C, Desjeux P, Alvar J. Leishmania/HIV co-infections in the second decade. Indian J Med Res 2006;123(3):357-388.

35. Cummings B, Mengistu M, Negash W, Bekele A, Ghile T. Barriers to and facilitators for female participation in an HIV prevention project in rural Ethiopia: findings from a qualitative evaluation. Cult Health Sex 2006;8(3):251-266.

36. Dawit A, Debella A, Dejene A, Abebe A, Mekonnen Y, Degefa A, et al. Is khat-chewing associated with HIV risk behaviour? A community-based study from Ethiopia. Afr J AIDS Res 2006;5(1):61-69.

37. Dare D, Fita A, Lindtjørn B. Acceptability of HIV counseling and testing among tuberculosis patients in south Ethiopia. Abstracts of the XVI International AIDS Conference; Toronto, Canada; 2006. Abstract no. WEPE0360.

38. Debela FH. Assessment of factors affecting the utilization of modern contraceptive methods among women in the reproductive age group in Angolelana Tera District, North Shoa Zone, ANRS. Unpublished MPH Thesis, Department of Community Health, Addis Ababa University; 2006.

39. Degfie TT. Correlates of domestic violence against women in Amhara Region: The case study of Bahir Dar Town. Unpublished MA Thesis, Institute of Development Research, Addis Ababa University; 2006.

40. Degu HG. Women's self-disclosure of HIV infection rates, rates, patterns, reasons and barriers. Unpublished MA Thesis, College of Education, Addis Ababa University, 2006.

41. Demissie M, Omer OA, Lindtjørn B, Hombergh Jvd. Tuberculosis. In: Berhane Y, Hailemariam D, Kloos H, editors. The Epidemiology and Ecology of Health and Disease in Ethiopia. 3rd ed. Addis Ababa, Ethiopia: Shama Books; 2006: p. 409-434.

42. Deneke K. Prevention of mother-to-child transmission of HIV/AIDS: KAP survey in selected urban areas. Abstracts of the XVIth Annual Conference of the Ethiopian Public Health Association; Addis Ababa, Ethiopia; 2005. Oral presentation no. 4.

43. Desta BY. Socio-economic and demographic factors determining rural women's contraceptive use in Sululta Woreda, Oromiya Region. Unpublished MA Thesis, Institute of Development Research, Addis Ababa University; 2006.

44. Drimie S, Tafesse G, Frayne B. RENEWAL Ethiopia background paper: HIV/AIDS, food and nutrition security. Geneva, Switzerland: International Food Policy Research Institute (IFPRI), January, 2006. (Available at: http://www.ifpri.org/renewal/pdf/RENEWALEthiopiaBG. pdf) 
45. Egata G. Assessment of level of knowledge of reproductive health and sexual behavior among adolescents in Nekemte Town. Abstracts of the XVIth Annual Conference of the Ethiopian Public Health Association; Addis Ababa, Ethiopia; 2005. Poster presentation no. 31.

46. Elemo I. HIV/AIDS risk perception among pastoral community leaders: The case of Borana pastoralists in southern Ethiopia. Abstracts of the XVI International AIDS Conference; Toronto, Canada; 2006. Abstract no. WEPE0655.

47. Elias D, Mengistu G, Akuffo H, Britton S. Are intestinal helminths risk factors for developing active tuberculosis? Trop Med Int Health 2006; 11(4):551-558.

48. Endris AY. Assessment of determinants of HIV VCT acceptance in Gondar Town. Unpublished MPH Thesis, Department of Community Health Addis Ababa University; 2006.

49. Engdaw AW. Socioeconomic and demographic determinants of unmet need for contraceptives among married women in rural Ethiopia. Unpublished MSc Thesis, Department of Statistics, Addis Ababa University; 2006.

50. Erulkar AS, Mekbib TA, Simie N, Gulema T. Differential use of adolescent reproductive health programs in Addis Ababa, Ethiopia. J Adoles Health 2006;38(3), 253-260.

51. Federal Ministry of Health. AIDS in Ethiopia: Sixth report. Addis Ababa, Ethiopia: Federal Ministry of Health; 2006.

52. Fitaw Y. Determinants of condom use and remaining faithful among Gondar College of Medicine and Health Science students, University of Gondar in northwest Ethiopia modular approach. Abstracts of the XVIth Annual Conference of the Ethiopian Public Health Association; Addis Ababa, Ethiopia; 2005. Poster presentation no. 2.

53. Furniss C. AIDS crisis 25 years on. Geographical 2006;78(1):47.

54. Garcia-Moreno C, Jansen HA, Ellsberg M, Heise L, Watts $\mathrm{CH}$. Prevalence of intimate partner violence: Findings from the WHO multi-country study on women's health and domestic violence. Lancet 2006;368(9543):1260-9.

55. Gebreeyesus SH. Assessment of HIV/AIDS related risks among men having sex with men (MSM) in Addis Ababa. Unpublished MPH Thesis, Department of Community Health, Addis Ababa University; 2006.

56. Gebremedhin YA. Assessment of willingness to VCT among pregnant mothers, attending antenatal care in Wukro and Kletawlela Woreda, Tigray Region. Unpublished MPH Thesis, Department of Community Health, Addis Ababa University; 2006.

57. Gebreselassie TT. How do people protect themselves from the dual risk of unintended preganancy and HIV/AIDS? Community based study in Adua Town, Tigray Region, Ethiopia. Unpublished MPH Thesis, Department of Community Health, Addis Ababa University; 2006.

58. Gedfa A, Mekonnen Y, Yimer G. Youth friendliness of sexual reproductive health (SRH) and HIV/AIDS services for young people: Study in eight selected regions of Ethiopia. Abstracts of the XVIth Annual Conference of the Ethiopian Public Health Association; Addis Ababa, Ethiopia; 2005. Poster presentation no. 14.

59. Gemeda TT. A comparative study of knowledge and practice of HIV counseling skills between governmental and non-governmental HIV counseling centers: The case of Gamo Gofa. Unublished MA Thesis, College of Education, Addis Ababa University, 2006.

60. Gile PP. Exploration of harmful traditional practices fueling the spread of HIV in Ethiopia. Horn Africa J AIDS 2006;3(2):25-30.

61. Girma A, Geyid A, Mekonen Z, Kebede T, Abebe A, Taye $\mathrm{G}$, et al. Etiologic patterns of common STI syndromes in Ethiopia. Abstracts of the XVIth Annual Conference of the Ethiopian Public Health Association; Addis Ababa, Ethiopia; 2005. Oral presentation no. 5.

62. Girma B. Assessment of risk behaviors for HIV/AIDS in adolescents, in Zeway Town, southern Ethiopia. Abstracts of the XVI International AIDS Conference; Toronto, Canada; 2006. Abstract no. WEPE0708.

63. Girma S, Mola M, Berhane Y. Assessment of sexual behavior and barriers to condom use among federal government employees in Addis Ababa. Abstracts of the XVIIth Annual Conference of the Ethiopian Public Health Association; Harar, Ethiopia; 2006. Abstract no. 31.

64. Gobeze A, Belete S, Azage T. Food security-nutrition and HIV/AIDS interface. Abstracts of the XVIth Annual Conference of the Ethiopian Public Health Association; Addis Ababa, Ethiopia; 2005. No abstract no.

65. Gossaye Y, Mulugeta E, Terefe H, Berhene Y. Gender and health. In: Berhane Y, Haile Mariam D, Kloos H, editors. The Epidemiology and Ecology of Health and Disease in Ethiopia. Shama Books, Addis Ababa; 2006: p.196-215.

66. Gugsa Y, Yared M, Tsehaynesh M, Yetnayet A, Ambaye D. An empirical investigation of the role of power in relationship on HIV risk awareness and the ability to communicate and negotiate safer sex in southern Ethiopia. Abstracts of the XVI International AIDS Conference; Toronto, Canada; 2006. Abstract no. THPE0650.

67. Gurmu YS. Demographic and socio-economic causes of female commercial sex work in Addis Ababa. Unpublished MA Thesis, Demographic Training and Research Center, Addis Ababa University; 2006.

68. Haddis M, Jerene D. Awareness of antenatal care clients on mother-to-child transmission (MTCT) of HIV infection and its prevention in Arba Minch. Ethiop J Health Dev 2006;20(1):55-57.

69. Hagos S, Hailemariam D. Assessment of HIV/AIDS risks among men having sex with men in Addis Ababa. Abstracts of the XVIIth Annual Conference of the Ethiopian Public Health Association; Harar, Ethiopia; 2006. Abstract no. 27.

70. Hagos TH. Determinants of young behavioral change to the risks of HIV/AIDS among the students of higher learning institutions in Addis Ababa: The case of some selected government and private colleges. Unpublished MA Thesis, Institute of Regional and Local Development Studies, Addis Ababa University; 2006.

71. Haile M, Deressa W, Berhane Y. Assessment of HIV/AIDS related knowledge among Window of Hope population of Kombolcha Town, South Wollo Zone, Amhara Regional State. Abstracts of the XVIth Annual Conference of the Ethiopian Public Health Association; Addis Ababa, Ethiopia; 2005. Poster presentation no. 13.

72. Haile T, Anderson SD. Visceral leishmaniasis in northern Ethiopia. East Afr Med J 2006;83(7):389-392.

73. Hailu YM. Sexual behavior, risk perception, and knowledge about HIV/AIDS among student-teachers in Debre Markos College of Teacher Education. Unpublished MA Thesis, Department of Psychology, Addis Ababa 
University; 2006.

74. Haregu TN. Developing a scale for measuring perceived barriers to behavioral change towards HIV/AIDS prevention. Unpublished MPH Thesis, Department of Community Health, Addis Ababa University; 2006.

75. Hladik W, Shabbir I, Jelaludin A, Woldu A, Tsehaynesh M, Tadesse W. HIV/AIDS in Ethiopia: Where is the epidemic heading? Sex Transm Infect 2006;82(Suppl 1):i32-i35.

76. Hussain T, Sinha S, Kulshreshtha KK, Katoch K, Yadav VS, Sengupta U, et al. Seroprevalence of HIV infection among leprosy patients in Agra, India: Trends and perspective. Int $\mathrm{J}$ Leprosy Other Mycobact Dis 2005;73(2):93-99.

77. Ismail S, Woldu A, Hladik W, Ahmed J, Wuhib T. HIV/AIDS estimates in Ethiopia, trends and programmatic challenges. Abstracts of the XVI International AIDS Conference; Toronto, Canada; 2006. Abstract no. WEPE0275.

78. Jimma KA. Knowledge about HIV/AIDS, risk reduction behavior and readiness to undergo voluntary counseling and testing for HIV: The case of college students in Arsi Zone. Unpublished MA Thesis, College of Education, Addis Ababa University, 2006.

79. John-Langba J, Woubalem Z. Disparities in economic development and associated perceptions about condoms in Ethiopia: Implications for HIV/AIDS. Abstracts of the XVI International AIDS Conference; Toronto, Canada; 2006. Abstract no. CDD1288.

80. Joshi R, Reingold AL, Menzies D, Pai M. Tuberculosis among health-care workers in low- and middle-income countries: A systematic review. PLoS Med. 2006;3(12):e494.

81. Kadiyala S. Socioeconomic predictors of prime-age adult mortality among the rural poor in Ethiopia. Abstracts of the XVI International AIDS Conference; Toronto, Canada; 2006. Abstract no. CDD0079.

82. Karau M, N. Betty, Bundi P. The great controversy on where AIDS is and where AIDS is going in Eastern Africa. Abstracts of the XVI International AIDS Conference; Toronto, Canada; 2006. Abstract number: CDC0443.

83. Kassa NA. Knowledge attitude and practice of workers towards HIV/AIDS \& VCT in selected service giving and manufacturing organization. Abstracts of the XVI International AIDS Conference; Toronto, Canada; 2006. Abstract number: THPE0984.

84. Kassa YT. Sexual activity and condom use among secondary school students in Debre Markos Town, Amhara Region. Unpublished MA Thesis, Demographic Training and Research Center, Addis Ababa University; 2006.

85. Kassie A, Shume A, Kloos H. Sexually transmitted infections. In: Berhane Y, Hailemariam D, Kloos $\mathrm{H}$, editors. The Epidemiology and Ecology of Health and Disease in Ethiopia. 3rd ed. Addis Ababa, Ethiopia: Shama Books; 2006: p. 435-445.

86. Kassu A, Moges F, Mengistu G, Mekonnen E, Zewde T, Wondmikun Y, et al. Seroprevalence of human immunodeficiency virus among blood donors in northwest Ethiopia, 1995-2002. Trop Doct 2006;36(2):106-107.

87. Kassu A, Tessema B, Mulu A, Yismaw G, Moges F, Mengistu G, et al. Declining trend in seroprevalence of HIV among blood donors in a tertiary level teaching hospital in Ethiopia: 1995-2005. Abstracts of the XVI
International AIDS Conference; Toronto, Canada; 2006. Abstract no. MOPE0548.

88. Kelkay WR. Knowledge, attitude and practice of contraceptives in Wukro Town, Tigray, Ethiopia. Unpublished MA Thesis, Demographic Training and Research Center, Addis Ababa University; 2006.

89. Kifetew K. The missed link - gender-based violence and HIV/AIDS. Abstracts of the XVI International AIDS Conference; Toronto, Canada; 2006. Abstract no. CDC0960.

90. Kifle WT. Fertility desire and family planning demand among HIV positive men and women in follow-up care in Addis Ababa antiretroviral treatment units. Unpublished MPH Thesis, Department of Community Health, Addis Ababa University; 2006.

91. Kloos H, Hailemariam D, Lindtjørn B. The HIV/AIDS epidemic in Ethiopia, with an emphasis on some neglected factors and their relevance to prevention and control. Abstracts of the XVIIth Annual Conference of the Ethiopian Public Health Association; Harar, Ethiopia; 2006. Abstract no. 26.

92. Lakew Y. Determinants of adopting HIV/AIDS preventive behaviors among taxi drivers and their assistants in Addis Ababa, Ethiopia. Abstracts of the XVIIth Annual Conference of the Ethiopian Public Health Association; Harar, Ethiopia; 2006. Abstract no. 49.

93. Lee S, Loha E, Shiferaw Y, Fenta H. Knowledge and perceived stigma in people living with HIV/AIDS in Jimma Town, southwestern Ethiopia. Abstracts of the XVI International AIDS Conference; Toronto, Canada; 2006. Abstract no. CDD0939.

94. Legesse B, Davey G, editors. Young people's HIV/AIDS and reproductive health needs and utilization of services in selected regions of Ethiopia. Addis Ababa, Ethiopia: Ethiopian Public Health Association; 2005.

95. Linsk N, Getu M, Johnson-Butterfield AK, Rollin J, Tasse A. HIV/AIDS in social work education in Ethiopia. Abstracts of the XVI International AIDS Conference; Toronto, Canada; 2006. Abstract no. CDD0812.

96. Lulseged S, Mekasha A, Berhane Y. Common childhood diseases. In: Berhane Y, Haile Mariam D, Kloos H, editors. The Epidemiology and Ecology of Health and Disease in Ethiopia. Shama Books, Addis Ababa, 2006: p. 325-338.

97. Mako TB. Determinants of marital stability among HIV positive women in Addis Ababa. Unpublished MA Thesis, Demographic Training and Research Center, Addis Ababa University; 2006.

98. Mekonen T, Petros B, Messele T, Girma M, Tilahum T, Meles $\mathrm{H}$, et al. Prevalence and risk factors of HIV-1 infection among blood donors in Addis Ababa, Ethiopia. Horn Africa J AIDS 2005;2(2):55-61.

99. Mekonen T, Petros B, Messele T, Tesfaye G, Girma M, Tilahun $\mathrm{T}$, et al. Assessment of transfusion risk for the transmission of HIV-1 at Addis Ababa blood bank center, Ethiopia. Abstracts of the XVI International AIDS Conference; Toronto, Canada; 2006. Abstract no. TUPE0392.

100. Mekonen T, Petros B, Tesfaye G, Girma M, Tilahun T, Mellese $\mathrm{H}$, et al. Prevalence and risk factors of HIV-1 infection among blood donors in Addis Ababa, Ethiopia. Abstracts of the XVI International AIDS Conference; Toronto, Canada; 2006. Abstract no. CDC0279.

101. Mekonnen Y, Areda A, Haile S. Explaining variation in 
contraceptive use between two community-based reproductive health $(\mathrm{CBRH})$ project area in Amhara Region: A study in Kutaber and Baso-na-Worana project areas. Abstracts of the XVIIth Annual Conference of the Ethiopian Public Health Association; Harar, Ethiopia; 2006. Abstract no. 32.

102. Mekonnen Y, Sanders E, Messele T, Wolday D, DorigoZestma W, Schaap A, et al. Prevalence and incidence of, and risk factors for, HIV-1 infection among factory workers in Ethiopia, 1997-2001. J Health Popul Nutr 2005;23(4):358-368.

103. Moges F, Kebede Y, Kassu A, Degu G, Tiruneh M, Gedefaw M. Infection with HIV and intestinal parasites among street dwellers in Gondar City, northwest Ethiopia. Jpn J Infect Dis 2006;59(6):400-403.

104. Moges SG. Assessment of sexual behavior and barriers to condom use among federal government employees in Addis Ababa. Unpublished MPH Thesis, Department of Community Health, Addis Ababa University; 2006.

105. Mohammed FI. Adolescents with hearing impairment and HIV/AIDS: Their awareness and sexual behavior. Unpublished MA Thesis, Department of Psychology, Addis Ababa University; 2006.

106. Muldoon K, Demessie A, Webber J, Ethiopian-NurseAssociation. Needle-stick injury: an investigative study by the Ethiopian nurse association. Abstracts of the XVI International AIDS Conference; Toronto, Canada; 2006. Abstract no. TUPE0551.

107. Nigatu T. Developing a scale for measuring perceived barriers to behavioral change towards HIV/AIDS prevention. Abstracts of the XVIIth Annual Conference of the Ethiopian Public Health Association; Harar, Ethiopia; 2006. Abstract no. 42.

108. Oljira L. Utilization of voluntary counseling and testing services, perceived barriers and preferences of adolescents of 15 to 24 years of age in Harar Town, eastern Ethiopia. Abstracts of the XVIth Annual Conference of the Ethiopian Public Health Association; Addis Ababa, Ethiopia; 2005. Oral presentation no. 3.

109. Omar M, Mohamed K. HIV/AIDS and female genital mutilation in the Somali's nomads of eastern Ethiopia: A discussion paper. World Hosp Health Serv 2006;42(3):2731.

110. Omer EM. Impact of substance abuse (khat) on sexual behaviour in vocational and college preparatory students in Awassa, South Ethiopia. Abstracts of the XVI International AIDS Conference; Toronto, Canada; 2006. Abstract no. CDD0590.

111. Roro MA. Assessment of the intention and practices of VCT and infant feeding in the context of HIV/AIDS among lactating mothers in Harar Town. Unpublished MPH Thesis, Department of Community Health, Addis Ababa University; 2006.

112. Salih MK. Determinants of contraceptive use among sexually active youth in urban Ethiopia. Unpublished MA Thesis, Institute of Development Research, Addis Ababa University; 2006.

113. Seifu A, Fantahun M, Worku A. Reproductive health needs of out-of-school adolescents: A cross-sectional comparative study of rural and urban areas in northwest Ethiopia. Ethiop J Health Dev 2006;20(1):10-17.

114. Shargie EB, Yassin MA, Lindtjorn B. Prevalence of smear-positive pulmonary tuberculosis in a rural district of Ethiopia. Int J Tuberc Lung Dis 2006;10(1):87-92.
115. Shiferaw MA. Assessment of the prevalence of premarital sex and unprotected sexual practice among Gedeo Zone high school students, SNNPR. Unpublished MPH Thesis, Department of Community Health, Addis Ababa University; 2006.

116. Shiferaw S, Fantahun M, Bekele A. The effect of perceived parental connectedness and monitoring on sexual risk behavior of high schools students, Dessie town, Ethiopia. Abstracts of the XVI International AIDS Conference; Toronto, Canada; 2006. Abstract no. TUPE0502.

117. Shimeles E, Aseffa A, Yamuah L, Tilahun H, Engers H. Knowledge and practice of private practitioners in TB control in Addis Ababa. Int $\mathrm{J}$ Tuberc Lung Dis 2006;10(10):1172-7.

118. Shin D. HIV/AIDS in Ethiopia: Past, present and future. Horn of Africa Journal of AIDS 2004;1(2):65-72.

119. Tarekegn YL. Determinants of adopting HIV/AIDS preventing behavior among taxi drivers and their assistants in Addis Ababa, Ethiopia. Unpublished MA Thesis, Demographic Training and Research Center, Addis Ababa University; 2006.

120. Tegbaru B, Wolday D, Messele T, Legesse M, Mekonnen Y, Miedema F, et al. Tuberculin skin test conversion and reactivity rates among adults with and without human immunodeficiency virus in urban settings in Ethiopia. Clin Vaccine Immunol 2006;13(7):784-789.

121. Tesfay W, Berhane Y. Sexual behavior of married military personnel: Does duty location matter? Abstracts of the XVIth Annual Conference of the Ethiopian Public Health Association; Addis Ababa, Ethiopia; 2005. Poster presentation no. 24.

122. Tesfaye R, Dibaba Y, Tegegn A. Sexual violence among female students in Jimma Town Jiren Senior Secondary and Preparatory School. Abstracts of the XVIth Annual Conference of the Ethiopian Public Health Association; Addis Ababa, Ethiopia; 2005. Poster presentation no. 31.

123. Teso DW. Assessment of premarital sexual practice among high school adolescents in Nekemte Town, Eastern Wollega Zone, Oromia Regional State. Unpublished MPH Thesis, Department of Community Health, Addis Ababa University; 2006.

124. Tessema AB. Gender stereotypes against females as a factor for HIV/AIDS vulnerability: The case of girls in two selected high schools in Yeka Sub-city Administration. Unpublished MA Thesis, Department of Psychology, Addis Ababa University; 2006.

125. Tsega AN. Factors influencing the motivation of youth in using and avoiding HIV-VCT services in some selected higher education institutes in Addis Ababa. Unpublished MA Thesis, Department of Psychology, Addis Ababa University; 2006.

126. Turasie AA. Association of HIV infection with some factors and modeling the chance of contracting HIV: The case of Awassa area. Unpublished MSc Thesis, Department of Statistics, Addis Ababa University; 2006.

127. UNAIDS. 2006 Report on the Global AIDS Epidemic. Geneva, Switzerland: UNAIDS; 2006.

128. UNAIDS. AIDS Epidemic Update: December 2006. Geneva, Switzerland: UNAIDS; 2006.

129. UNAIDS. AIDS epidemic update 2006: Sub-Saharan Africa. Geneva, Switzerland: UNAIDS; 2006.

130. Wassie E, Nemero R, Bassie A, Esayas Y, Beshah A, Letamo Y. Knowledge, perceptions and willingness to use 
antiretroviral therapy in Yirgalem Town, southern Ethiopia. Abstracts of the XVIIth Annual Conference of the Ethiopian Public Health Association; Harar, Ethiopia; 2006. Abstract no. 20.

131. Watts C, Heise L, Mary E, Jansen H, Jessie M, Churnrurtai $\mathrm{K}$, et al. Violence against women and HIV associated risk: findings from the WHO 10 country study on women's health and domestic violence. Abstracts of the XVI International AIDS Conference; Toronto, Canada; 2006. Abstract no. THPE0692.

132. Woldegiorgis AM. Sexual behavior among visually impaired women and vulnerability to HIV/AIDS: The case of Ethiopian National Association of the Blinds in Addis Ababa. Unpublished MA Thesis, Institute of Development Research, Addis Ababa University; 2006.

133. Wondwossen D, Mengisteab S. Occupational exposure of health workers to blood/ body fluids of patients in Addis Ababa hospitals, Ethiopia. Abstracts of the XVI International AIDS Conference; Toronto, Canada; 2006. Abstract no. CDD1142.

134. Worku D, Gebremariam A, Jayalakshmi S. Child sexual abuse and its outcomes among high school students in southwest Ethiopia. Trop Doct 2006;36(3):137-40.

135. Yeneneh BT, Gebremariam A, Belachew T. Knowledge, attitude and practice (KAP) of home based care (HBC) for HIV/AIDS patients in Jimma Town, southwest Ethiopia. Abstracts of the XVI International AIDS Conference; Toronto, Canada; 2006. Abstract no. CDB0953.

136. Yimam Z, Berhane Y. Determinant of VCT utilization among youth in Jijiga Town, Ethiopia. Abstracts of the XVIth Annual Conference of the Ethiopian Public Health Association; Addis Ababa, Ethiopia; 2005. Poster presentation no. 11.

137. Zewdie Z, Ali A. Assessment of HIV perception and condom use among youth in Debre Birhan Town, Amhara Region. Abstracts of the XVIth Annual Conference of the Ethiopian Public Health Association; Addis Ababa, Ethiopia; 2005. Oral presentation no. 9.

138. Zimmerman R, Cupp P, Donohew L, Bhana A, Kebede W. Adapting a western health behavior model for African populations: Explaining sexual initiation in South Africa and Ethiopia with the multiple domain model. Abstracts of the XVI International AIDS Conference; Toronto, Canada; 2006. Abstract no. CDC0675.

\section{Section 4. Clinical Research}

This section includes studies on the characteristics and clinical course of HIV infection and opportunistic infections, and other clinical issues affecting HIV/AIDS patients.

1. Abdosh A, Awano-Lemtuche T, Abashawl A, Gudetta BG, Adamu R, Ruff A, et al. Failure to thrive as a predictor of HIV infection in a population with high background rate of malnutrition. Abstracts of the XVI International AIDS Conference; Toronto, Canada; 2006. Abstract no. MOPE0227.

2. Addissie A, Deressa W, Enqusselassie F. HIV and malaria co-infection; pattern and clinical features, in Hadya Zone, Southern Ethiopia. Abstracts of the XVI International AIDS Conference; Toronto, Canada; 2006. Abstract no. CDB0307.

3. Aderaye G, Ali G, Demissie BK. Anti-tubercular druginduced hepatotoxicity in HIV-positive and negative patients. Abstracts of the XVI International AIDS Conference; Toronto, Canada; 2006. Abstract number:
MOPE0214.

4. Akhlaghi L. The analysis of ART regimens used in seven developing countries: Impact on forecasting needs and rational drug use. Abstracts of the XVI International AIDS Conference; Toronto, Canada; 2006. Abstract no. WEPE0080.

5. Behar DM, Shlush LI, Maor C, Lorber M, Skorecki K. Absence of HIV-associated nephropathy in Ethiopians. Am J Kidney Dis 2006;47(1):88-94.

6. Cranmer LM, Gudetta B, Bedri A, Abashawl A, Omer S, Adamu R, et al. Total lymphocyte count (TLC) as a predictor of mortality among HIV-infected infants in Ethiopia. Abstracts of the XVI International AIDS Conference; Toronto, Canada; 2006. Abstract no. CDB0123.

7. Dare D, Næss A, Lindtjørn B. Antiretroviral therapy improves survival and decreases tuberculosis in Ethiopian HIV patients. Abstracts of the XVI International AIDS Conference; Toronto, Canada; 2006. Abstract no. WEPE0067.

8. Elias D, Akuffo H, Britton S. Helminthes could influence the outcome of vaccines against TB in the tropics. Parasite Immunology 2006;28(10):507-513.

9. Endesaw T, Zewdie A, Tsige K, Kebede A, Dereje AS, Hailu E, et al. Cryptosporidium parvum and Isospora belli infections among diarrhea patients infected with HIV-1 in Addis Ababa, Ethiopia. Abstracts of the XVIth Annual Conference of the Ethiopian Public Health Association; Addis Ababa, Ethiopia; 2005. Poster presentation no. 9.

10. Endeshaw T, Kebede A, Verweij JJ, Zewide A, Tsige K, Abraham $\mathrm{Y}$, et al. Intestinal microsporidiosis in diarrheal patients infected with human immunodeficiency virus-1 in Addis Ababa, Ethiopia. Jpn J Infect Dis 2006;59(5):306310.

11. Federal Ministry of Health. Guideline for Cotrimoxazole prophylaxis in HIV/AIDS care and treatment. Addis Ababa, Ethiopia: Federal Ministry of Health; 2006.

12. Geyid A, Girma A, Kebede T, Shume A, Abebe A. Etiologies of genital ulcers disease (GUD) in Ethiopia and implication for syndromic case management. Abstracts of the XVIth Annual Conference of the Ethiopian Public Health Association; Addis Ababa, Ethiopia; 2005. Oral presentation no. 2.

13. Geyid A, Girma A, Kebede AT, Abebe A, Shume A. Etiologies of genital ulcers disease (GUD) in Ethiopia and implications for syndromic case management. Abstracts of the XVI International AIDS Conference; Toronto, Canada; 2006. Abstract no. CDC0616.

14. Girma A. Primary HIV infection (PHI) in patients presenting with conventional sexually transmitted infections (STI) in Ethiopia: Magnitude and risk factors. Unpublished MPH Thesis, Department of Community Health, Addis Ababa University; 2006.

15. Girma A, Geyid A, Mekonen Z, Kebede T, Abebe A, Taye $\mathrm{G}$, et al. Validation of the syndromic algorithm approach for the management of sexually transmitted infections in Ethiopia. Abstracts of the XVIth Annual Conference of the Ethiopian Public Health Association; Addis Ababa, Ethiopia; 2005. Oral presentation no. 6.

16. Gudetta B, Mengistu Y, Adamu R, Abashawl A, Ruff A, Bedri A. Correlation between Total Lymphocyte Count (TLC) and CD4 count in HIV exposed and infected infants. Abstracts of the XVI International AIDS Conference; Toronto, Canada; 2006. Abstract no. 
MOPE0245.

17. Hassoun G, Kedem E, Shahar E, Pollack S. Recurrent episodes of immune reconstitution syndrome in HIV patient. Abstracts of the XVI International AIDS Conference; Toronto, Canada; 2006. Abstract no. CDB0311.

18. Ililo RI. Dilemmas in the diagnosis of lymph node enlargement in Ethiopia: A study from four sites with a high notification of lymph node tuberculosis. Unpublished MSc Thesis, Department of Medical Microbiology, Immunology and Parasitology Addis Ababa University; 2006.

19. Jerene D, Endale A, Hailu Y, Lindtjorn B. Predictors of early death in a cohort of Ethiopian patients treated with HAART. BMC Infect Dis 2006;6:136.

20. Kassu A, Nishizawa M, Diro E, Ayele B, Mengistu G, Fujino $M$, et al. Human immunodeficiency virus-1 RNA levels in tuberculosis patients with or without intestinal parasites during treatment of tuberculosis in Gondar, Ethiopia. Abstracts of the XVI International AIDS Conference; Toronto, Canada; 2006. Abstract no. CDB0269.

21. Kassu A, Yabutani T, Mahmud ZH, Mohammad A, Nguyen N, Huong BTM, et al. Alterations in serum levels of trace elements in tuberculosis and HIV infections. Eur J Clin Nutr 2006;60(5):580-586.

22. Kebede A, Endeshaw $\mathrm{T}$, Verwei J, Messle $\mathrm{T}$, Woldemichael T, Mekonnen $\mathrm{Y}$, et al. Association of Entamoeba dispar infection with disease progression among HIV/AIDS patients with complaints of diarrhea from three hospitals in Addis Ababa. Abstracts of the XVIth Annual Conference of the Ethiopian Public Health Association; Addis Ababa, Ethiopia; 2005. Poster presentation no. 15.

23. Mamo G, Mihret A, Gebru G, Afewwork M, Demissie A, Yamuah LK, et al. Human immune responses to antigens of Mycobacterium tuberculosis relevant to non-replicating persistent (NRP) TB in an endemic population of Ethiopia. Abstracts of the XVIth Annual Conference of the Ethiopian Public Health Association; Addis Ababa, Ethiopia; 2005. Poster presentation no. 5.

24. Mitsunaga $T$, Seung $K$, Celletti F, Gove S. Operationalizing patient monitoring for HIV care and ART. Abstracts of the XVI International AIDS Conference; Toronto, Canada; 2006. Abstract no. CDE0142.

25. Moges F, Kassu A, Mengistu G, Adugna S, Andualem B, Nishikawa T, et al. Seroprevalence of Helicobacter pylori in dyspeptic patients and its relationship with HIV infection, ABO blood groups and life style in a university hospital, northwest Ethiopia. World J Gastroenterol 2006;12(12):1957-1961.

26. Ramos JM, Reyes F, Tesfamariam A. Intestinal parasites in adults admitted to a rural Ethiopian hospital: Relationship to tuberculosis and malaria. Scan J Infec Dis 2006;38(6-7):460-462.

27. Riesenberg K, Alkan M, Borer A, Smolikov R, Karp E, Gilad Y, et al. Improvement of Immunologic and virologic markers in low compliant HIV population by drug dispensing (DD) at the clinic. Abstracts of the XVI International AIDS Conference; Toronto, Canada; 2006. Abstract no. TUPE0145.

28. Ritmeijer K, Dejenie A, Assefa Y, Hundie TB, Mesure J, Boots G, et al. A Comparison of Miltefosine and Sodium
Stibogluconate for treatment of visceral leishmaniasis in an Ethiopian population with high prevalence of HIV infection. Clin Infect Dis 2006;43(3):357-364.

29. Shah NS, Demissie M, Teshager G, Lambert L, Lemma E, Seife $\mathrm{E}$, et al. Intensified case finding for pulmonary tuberculosis among HIV-infected persons from a voluntary counseling and testing clinic in Addis Ababa, Ethiopia. Abstracts of the XVI International AIDS Conference; Toronto, Canada; 2006. Abstract no. MOPE0184.

30. Siberry GK, Tessema S. Immune reconstitution syndrome precipitated by bacille Calmette Guerin after initiation of antiretroviral therapy. Pediatric Infect Dis J 2006;25(7):648-649.

31. Siraj DS, Abebe Y. Chronic diarrhea in an HIV/AIDS patient: Case presentation and summary discussion. Horn Africa J AIDS 2006;3(2):12-15.

32. Tadios Y. Antiretoviral treatment adherence and its correlates among people living with HIV/AIDS on highly active antiretroviral therapy in Addis Ababa, Ethiopia. Abstracts of the XVIth Annual Conference of the Ethiopian Public Health Association; Addis Ababa, Ethiopia; 2005. Oral presentation no. 8.

33. Tolla L. Assessing the quality of life (QOL) of people living with HIV/AIDS on highly active antiretroviral therapy in Zenebework Hospital, Addis Ababa. Abstracts of the XVIIth Annual Conference of the Ethiopian Public Health Association; Harar, Ethiopia; 2006. Abstract no. 71.

34. Wolday D, Berhanu H, Yohannes S, Asmare Y, Meles H, Girma M, et al. Survival of human immunodeficiency virus (HIV) infected patients after initiating antiretroviral treatment (ART) in Ethiopia. Abstracts of the XVI International AIDS Conference; Toronto, Canada; 2006. Abstract no. CDB0596.

35. Woldearegay LT. Assessing the quality of life of people with HIV/AIDS with highly active antiretroviral treatment in Addis Ababa's Zenebe Work Hospital. Unpublished MPH Thesis, Department of Community Health, Addis Ababa University; 2006.

\section{Section 5. Impacts Research}

This section covers studies on the social, psychological, economic, and demographic impacts of HIV/AIDS on individuals, families, communities, institutions, or the nation. In addition, studies that explore relevant social issues associated with the spread of the HIV/AIDS are also included.

1. Adeba DG. Adjustment challenges to healthy psychosocial development of AIDS-orphaned adolescents of Adama Town. Unpublished MA Thesis, Department of Psychology, Addis Ababa University; 2006.

2. Adjuik M, Smith T, Clark S, Todd J, Garrib A, Kinfu Y, et al. Cause-specific mortality rates in sub-Saharan Africa and Bangladesh. Bull World Health Org 2006;84(3):181$188 \mathrm{D}$.

3. Admassu Sahle A, Hailu Yitaferu A. Academic performance of orphans: Best practices. Abstracts of the XVI International AIDS Conference; Toronto, Canada; 2006. Abstract no. MOPE0832.

4. Aklilu HB. Assessment of the cause of death and characteristics of chronic illnesses in Addis Ababa with emphasis on HIV/AIDS. Unpublished MPH Thesis, Department of Community Health, Addis Ababa University; 2006.

5. Asmare MT. HIV/AIDS and its impacts on the traditional 
support networks of the elderly: The case of Arada SubCity in Addis Ababa. Unpublished MA Thesis, School of Social Work, Addis Ababa University; 2006.

6. Ayele MR. The socioeconomic impact of HIV/AIDS on households: The case of Nazareth Town. Unpublished MA Thesis, Department of Sociology and Social Anthropology, Addis Ababa University; 2006.

7. Balcha DM. The psychosocial behavior of AIDS orphans: The case of AIDS orphans in five organizations in Awassa. Unpublished MA Thesis, College of Education, Addis Ababa University, 2006.

8. Balderas HM. Assessing the impact of early parent loss on the psychosocial and behavioral development of institutionalized HIV orphans. Unpublished MA Thesis, Department of Psychology, Addis Ababa University; 2006.

9. Belete RY. Survival strategies of people living with HIV/AIDS in and around Intoto. Unpublished MA Thesis, Department of Sociology and Social Anthropology, Addis Ababa University; 2006.

10. Bhargava A. AIDS epidemic and the psychological wellbeing and school participation of Ethiopian orphans. Psychol Health Med 2005;10(3):263-275.

11. Chilu GN. Stigma and discrimination of HIV/AIDS orphans in the case of orphans supported by CHAD-ET. Unpublished MA Thesis, School of Social Work, Addis Ababa University; 2006.

12. Deribew A, Tessema F, Girma B. Determinants of underfive mortality in the communities around Gilgel Gibe hydroelectric dam, south western Ethiopia: A case control study. Abstracts of the XVIIth Annual Conference of the Ethiopian Public Health Association; Harar, Ethiopia; 2006. Abstract no. 57.

13. Ejigu GT. Situational analyses of orphan and vulnerable children in Bahir Dar Town, Northwestern Ethiopia. Unpublished MA Thesis, School of Social Work, Addis Ababa University; 2006.

14. Gizachew B. Prevalence and socio-demographic correlates of mental distress in people living with HIV/AIDS, Jimma Town. Abstracts of the XVIIth Annual Conference of the Ethiopian Public Health Association; Harar, Ethiopia; 2006. Abstract no. 13.

15. Gottesman E. Video, memory and participation: What we can learn from AIDS OVCs. Abstracts of the XVI International AIDS Conference; Toronto, Canada; 2006. Abstract no. TUAE0201.

16. Habtu B. Assessing the macroeconomic impact of HIV/AIDS: The Ethiopian case. Unpublished MA Thesis, Department of Economics, Addis Ababa University, 2006.

17. Hassen KA. Psychosocial problems of HIV/AIDS orphans: A case study of six HIV/AIDS orphans in Harar. Unpublished MA Thesis, Department of Psychology, Addis Ababa University; 2006.

18. Hussen TW. The situation of HIV/AIDS infected and affected people in Dessie Town, Amhara Regional State, Ethiopia. Unpublished MA Thesis, School of Social Work, Addis Ababa University; 2006.

19. Kassaw KN. Resilience, coping, and support of AIDS orphaned children in Arada Sub-city, Addis Ababa: Comparison of the experiences of younger and older children. Unpublished MA Thesis, Department of Psychology, Addis Ababa University; 2006.

20. Kidanu A, Banteyerga H, Nyblade LC, MacQuarrie K, Pande R, Mathur S. Impact of stigma on wellbeing of
PLHA in Ethiopia. Abstracts of the XVI International AIDS Conference; Toronto, Canada; 2006. Abstract no. TUPE0708.

21. Mattanovich D. AIDS orphans: Voiceless victims. Horn Africa J AIDS 2005;2(1):21-25.

22. Phillipos P. The impact of HIV/AIDS on orphans and the challenge to development, the case of Addis Ababa. Horn Africa J AIDS 2005;2(2):21-25.

23. Reniers G, Araya T, Sanders EJ. Life table estimates of adult HIV/AIDS mortality in Addis Ababa. Ethiop J Health Dev 2006;20(1):3-9.

24. Ruff A, Gudetta B, Awano-Lemtuche T, Abdosh A, Hailu D, Adamu R, et al. Infant morbidity and mortality by HIV exposure and infection status. Abstracts of the XVI International AIDS Conference; Toronto, Canada; 2006. Abstract no. MOPE0077.

25. Shiferaw W. The economic impact of HIV/AIDS on Gulele Garment Share Company. Unpublished MA Thesis, Institute of Regional and Local Development Studies, Addis Ababa University; 2006.

26. Tegbaru B, Kebede M, Yohannes S, Baarle Dv, Meless H, Miedema F, et al. Mortality in Mycobacterium tuberculosis patients co-infected with human immunodeficiency virus before and in the era of antiretroviral therapy. Abstracts of the XVIIth Annual Conference of the Ethiopian Public Health Association; Harar, Ethiopia; 2006. Abstract no. 30.

27. Teklemedhin TM. Needs, problems and responses to the situation of AIDS orphans and other vulnerable children (OVC): The case of Lideta Sub-City, Kebele 01/18. Unpublished MA Thesis, School of Social Work, Addis Ababa University; 2006.

\section{Section 6. Intervention Research}

This section includes reports on research and programmatic activities that are aimed at provision of treatment, care, and support to people infected and affected by HIV. This section also includes reports on prevention efforts and public policy measures targeted against HIV/AIDS.

1. Abebe Y, Messele A, Simmons N. Developing an effective care and referral network in the context of rapid ART scale-up: Addis Ababa, Ethiopia. Abstracts of the XVI International AIDS Conference; Toronto, Canada; 2006. Abstract no. TUPE0225.

2. Abebe Y, Selassie D, Ejigu S, Lekasse R, Harris C, Siraj $\mathrm{D}$, et al. Community based, multi-partnership care model improves adherence in resource-limited settings. Abstracts of the XVI International AIDS Conference; Toronto, Canada; 2006. Abstract no. THPE0218.

3. Abraham FA. Social significance of ETV dramas (plays) on HIV/AIDS awareness creation and behavioral change. Unpublished MA Thesis, Institute of Language Studies, Addis Ababa University; 2006.

4. Abraham S, Burka Y, Khan N, Bhatt P. The potential for social franchising to address HIV/AIDS and tuberculosis in Ethiopia. Abstracts of the XVI International AIDS Conference; Toronto, Canada; 2006. Abstract no. CDD1134.

5. Abraham S, Burka Y, Khan N, Bhatt P. Financing mechanisms for HIV/AIDS care and treatment: social safety-net schemes to save lives and businesses in Ethiopia. Abstracts of the XVI International AIDS Conference; Toronto, Canada; 2006. Abstract no. CDD1192. 
6. Addissie A, Hiwot HG, Genebo T. FBO-government collaboration on expansion of city wide PMTCT program: Case study of the collaboration between the Ethiopian Kale Heywot Church (EKHC) and the Addis Ababa Health Bureau, Addis Ababa, Ethiopia. Abstracts of the XVI International AIDS Conference; Toronto, Canada; 2006. Abstract no. THPE0597.

7. Admassu RA. Design and development of a prototype knowledge base system for HIV pretest counseling. Unpublished MA Thesis, Department of Information Science, Addis Ababa University; 2006.

8. Alito FJ. The differential effect of VCT service in reducing HIV risk behaviors among VCT and non-VCT groups in some selected sub-cities in Addis Ababa. Unpublished MA Thesis, College of Education, Addis Ababa University, 2006.

9. Amare AS, Lemma W, Aklilu A. Free ART services increasing female participation in treatment: Experience in treating more than 4000 patients in a large regional hospital in Addis Ababa, Ethiopia. Abstracts of the XVI International AIDS Conference; Toronto, Canada; 2006. Abstract no. CDB1289.

10. Amberbir A, Deribe K, Lingerh W, Getachew B, Dejene $\mathrm{Y}$. Uptake of voluntary counseling and testing (VCT) and correlates among women attending antenatal care (ANC): Implication to prevention of mother to child transmission (PCMT) of human immunodeficiency virus (HIV), southwest Ethiopia. Abstracts of the XVIth Annual Conference of the Ethiopian Public Health Association; Addis Ababa, Ethiopia; 2005. Oral presentation no. 1.

11. Anema A, Ritmeijer K. Treating HIV/AIDS and leishmaniasis coinfection in Ethiopia. Canadian Med Assoc J 2005; 172(11):1434-1435.

12. Asnake M. and Abera $\mathrm{Y}$. Health facility readiness to provide youth-friendly reproductive health and family planning services. Abstracts of the $33^{\text {rd }}$ Annual International Conference on Global Health, Washington, DC; 2006. Poster abstract no. 1.

13. Asnake M, Walie L, Melkamu Y. Improving the range of contraceptive choices in rural Ethiopia. Ethiop J Health Dev 2006;20(2):74-78.

14. Asnake M, Woldegiorgis $\mathrm{M}$. The provision of home based care services for AIDS patients through community volunteers in Ethiopia. Abstracts of the XVI International AIDS Conference; Toronto, Canada; 2006. Abstract no. CDB0951.

15. Assefa T, Stuer F. Developing community linkages: Collaboration towards a comprehensive response to care and support -the case of Ethiopia. Abstracts of the XVI International AIDS Conference; Toronto, Canada; 2006. Abstract no. TUPE0933.

16. Aunt K, Besser M, Mbono B. Mothers 2 Mothers: Education, counseling and psychosocial support in PMTCT programs in Africa. A replicable and sustainable model for care. Abstracts of the XVI International AIDS Conference; Toronto, Canada; 2006. Abstract no. TUPE0696.

17. Ayalew L. Ensuring access to prevention services among mobile populations in Ethiopia: opportunities and challenges. Abstracts of the XVI International AIDS Conference; Toronto, Canada; 2006. Abstract no. CDD0136.

18. Azage T. Development of the training manual on nutritional care and support for PLWHA. Abstracts of the
XVIth Annual Conference of the Ethiopian Public Health Association; Addis Ababa, Ethiopia; 2005. No abstract number.

19. Belay AD, Asafa Y, Mesure J, Davidson RN. Successful miltefosine treatment of post-kala-azar dermal leishmaniasis occurring during antiretroviral therapy. Ann Trop Med Parasitol 2006;100(3):223-227.

20. Betele S, Argaw K, Dibaba S. Education of the general public and HIV positive members. Abstracts of the XVI International AIDS Conference; Toronto, Canada; 2006. Abstract no. CDC1992.

21. Biazin AM, Negasse AK, Kitaw AS. Rapid scaling up of an effective basic HIV/AIDS health sector intervention programs in the context of public and NGOS partnership response: Amhara National Regional State, Ethiopia. Abstracts of the XVI International AIDS Conference; Toronto, Canada; 2006. Abstract no. CDB1229.

22. Biru A, Girma A, Stuer F, Teferi T, Assefa T. BCC campaign to reduce stigma and discrimination in Addis Ababa, Ethiopia. Abstracts of the XVIth Annual Conference of the Ethiopian Public Health Association; Addis Ababa, Ethiopia; 2005. Poster presentation no. 7.

23. Biru A, Stuer F. Efforts to motivate behavior change through production and use of a music video. Abstracts of the XVI International AIDS Conference; Toronto, Canada; 2006. Abstract no. THPE0371.

24. Creanga AA, Bradley H, Kidanu A, Melkamu Y, Tsui A. Community health workers' roles in delivering integrated family planning and HIV/AIDS services in Ethiopia. Abstracts of the XVI International AIDS Conference; Toronto, Canada; 2006. Abstract no. WEPE0925.

25. Curran K, Abduljewad Y, Ruparelia C, Kebede T, Wyss S, Kyei A, et al. Innovative approaches to increase uptake of HIV counseling and testing services in Ghana, Ethiopia and the Caribbean region. Abstracts of the XVI International AIDS Conference; Toronto, Canada; 2006. Abstract no. WEPE0337.

26. Davey G, Fekade D, Parry E. Must aid hinder attempts to reach the Millennium Development Goals? Lancet 2006;367(9511):629-631.

27. Dayel S. Improving household income of women affected by HIV/AIDS in Ethiopia. Abstracts of the XVI International AIDS Conference; Toronto, Canada; 2006. Abstract no. CDD1167.

28. Dessiye M. Care and support service for PLWHA and AIDS orphans in religious institutions: The case of Dessie Town. Unpublished MA Thesis, Department of Sociology and Social Anthropology, Addis Ababa University; 2006.

29. Dia O. Making medical injections safer. Abstracts of the XVIth Annual Conference of the Ethiopian Public Health Association; Addis Ababa, Ethiopia; 2005. No abstract number.

30. Drager S, Gedik G, Dal Poz MR. Health workforce issues and the Global Fund to fight AIDS, Tuberculosis and Malaria: An analytical review. Hum Resou Health 2006;24(4):23 [electronic publication].

31. Dombo M. Building partnerships that work: Lessons and case studies from HACI. Abstracts of the XVI International AIDS Conference; Toronto, Canada; 2006. Abstract no. CDE0483.

32. Dugasa M. Problems and challenges in the implementation of anti-HIV/AIDS activities in Nekemte Town, southwest Ethiopia. Unpublished MA Thesis, Institute of Regional and Local Development Studies, Addis Ababa University; 
2006.

33. Ejigsemahu Y. The evolving role of youth in the fight against the HIV/AIDS pandemic. Abstracts of the XVIIth Annual Conference of the Ethiopian Public Health Association; Harar, Ethiopia; 2006. Abstract no. 23.

34. Ejigsemahu $\mathrm{Y}$, Kane M. The evolving role of youth in the fight against the HIV/AIDS pandemic. Abstracts of the XVI International AIDS Conference; Toronto, Canada; 2006. Abstract no. THPE0406.

35. Elemo IA. HIV/AIDS, Gender and Reproductive Health Promotion: The Role of Traditional Institutions among the Borana Oromo, Southern Ethiopia. Contemporary Issues in Borana and the 38th Gumi Gaayo. Assembly. Artistic Printing, Addis Ababa, 2005.

36. Elemo I. HIV/AIDS intervention and the roles of traditional institutions in Ethiopia: The case of Oromiya national state. Abstracts of the XVI International AIDS Conference; Toronto, Canada; 2006. Abstract no. CDD1299.

37. El-Sadr W, Elul B, Rabkin M, Hawken M, Lima J, Macharia D, et al. Rapid expansion of HIV/AIDS care and treatment programs in 6 Sub-Saharan countries. Abstracts of the XVI International AIDS Conference; Toronto, Canada; 2006. Abstract no. CDB1122.

38. Endalew WG. HIV/AIDS pandemic in the Horn of Africa: Political response and implications to international relations. Unpublished MA Thesis, Department of Political Science and International Relations, Addis Ababa University, 2006.

39. Engelhard D, Turner D, Grossman Z, Gebrekidan T, Wolday D, Mengistu Y, et al. The Israeli Consortium on AIDS Medicine (ICAM) - collaboration and programs in Ethiopia 2004-2006. Abstracts of the XVI International AIDS Conference; Toronto, Canada; 2006. Abstract no. CDB1090.

40. Ergete AH. Role of faith based organization in combating HIV/AIDS epidemic in Addis Ababa: Case study of Ethiopian Kale Heywet Church. Unpublished MA Thesis, School of Social Work, Addis Ababa University; 2006.

41. Eshete EF. Reducing youth vulnerability in Ethiopia through social purpose enterprise. Abstracts of the XVI International AIDS Conference; Toronto, Canada; 2006. Abstract no. MOPE0879.

42. Federal Ministry of Health, Disease Prevention and Control Department. Accelerating Access to HIV/AIDS Treatment in Ethiopia: Road Map for 2004-2006. Federal Ministry of Health, Disease Prevention and Control Department, 2006.

43. Federal Ministry of Health/HAPCO. Monthly HIV Care and ART Update. Monthly updates for FebruaryDecember 2006. Addis Ababa, Federal Ministry of Health/HAPCO, 2006.

44. Fieno J. Africa's human resources deficit in health and a cost projection of how to meet the WHO physician targets by 2012. Abstracts of the XVI International AIDS Conference; Toronto, Canada; 2006. Abstract no. CDD1198.

45. Gebeyehu K. Successful large scale prevention of mother to child transmission (PMTCT) of HIV in resource limited countries: Is availability and affordability of antiretroviral(s) the whole answer? Horn Africa J AIDS 2006;3(2):20-24.

46. Ghenna K, Gold J, Tekallign T, Atacik MC. Mobilizing business-led response to AIDS in Ethiopia. Abstracts of the XVI International AIDS Conference; Toronto, Canada; 2006. Abstract no. TUKC404.

47. Gillespie S. RENEWAL in Africa: An innovative approach to linking research, capacity strengthening and policy impact on a neglected issue. Abstracts of the XVI International AIDS Conference; Toronto, Canada; 2006. Abstract no. THPE0848.

48. Gizaw Z, Kane M. Gaps in comprehensive care: Challenges for effective CHBC in Awassa, Ethiopia. Abstracts of the XVI International AIDS Conference; Toronto, Canada; 2006. Abstract no. CDB0947.

49. Gold J, Tekallign T, Ghenna K. Technical assistance for HIV/AIDS workplace program development. Abstracts of the XVI International AIDS Conference; Toronto, Canada; 2006. Abstract no. WEPE0464.

50. Haileyesus MG. Protecting the child and saving the mother: Integrating PMTCT in maternal and child health services. Abstracts of the XVI International AIDS Conference; Toronto, Canada; 2006. Abstract no. THPE0781.

51. Hailu D. The implications of institution vs. community centered approaches in HIV/AIDS interventions in Africa: The case of government-led vs. faith based responses in Ethiopia. Abstracts of the XVI International AIDS Conference; Toronto, Canada; 2006. Abstract no. CDE0088.

52. Hamel N, Muldoon K, Walji M. Youth interns in Ethiopia. Can Nurse 2006;102(6):21-23.

53. Jerene D, Naess A, Lindtjorn B. Antiretroviral therapy at a district hospital in Ethiopia prevents death and tuberculosis in a cohort of HIV patients. AIDS Res Ther 2006;3(10): [electronic publication].

54. Kaba M. Paradigm shift in communication in HIV/AIDS prevention: Lessons learnt in Ethiopia. Abstracts of the XVIIth Annual Conference of the Ethiopian Public Health Association; Harar, Ethiopia; 2006. Abstract no. 72.

55. Kaba M, Alem A. Integrating youth friendly VCT to youth reproductive health service provision: Experience from Family Guidance Association of Ethiopia (FGAE) youth centers. Abstracts of the XVIIth Annual Conference of the Ethiopian Public Health Association; Harar, Ethiopia; 2006. Abstract no. 77.

56. Kassa NA. Factors influencing effective HIV mainstreaming in Addis Ababa education system. Unpublished MPH Thesis, Department of Community Health, Addis Ababa University; 2006.

57. Kassahun A. Establishing structures for donor-donor and other key stakeholders dialogue and consensus building around HIV/AIDS in Ethiopia. Abstracts of the XVI International AIDS Conference; Toronto, Canada; 2006. Abstract no. CDE0595.

58. Kassaye SG, Ndayishimiye F, Binswanger H, Sall AY, Machekano R, Israelski DM. Association-driven care and treatment: A model for community-based delivery of HIV/AIDS healthcare in resource-limited settings. AIDS 2006; 20(11):1561-62.

59. Kayanja R. Antiretroviral drugs for all? Aiming for universal treatment for HIV/AIDS in Ethiopia, Haiti, India, Nepal and Zambia. Abstracts of the XVI International AIDS Conference; Toronto, Canada; 2006. Abstract no. CDD1481.

60. Kebede T, Wuhib T, Asrat A, Mariam BG, Ismail S, Negassa H. The impact of public HIV testing of political leaders and prominent figures in VCT service utilization. 
Abstracts of the XVI International AIDS Conference; Toronto, Canada; 2006. Abstract no. WEPE0369.

61. Kereta W, Stuer F, Teferi T, Assefa T. Home and community-based care scale up in Ethiopia. Abstracts of the XVIth Annual Conference of the Ethiopian Public Health Association; Addis Ababa, Ethiopia; 2005. Poster presentation no. 8.

62. Kerr C. Clinton Foundation to help Ethiopian HIV/AIDS plan. Lancet Infect Dis 2006;6(3):132.

63. Kidane WT. Communities volunteers home-based care of HIV/AIDS patients. Unpublished MPH Thesis, Department of Community Health, Addis Ababa University; 2006.

64. Kifetew K. Communicating with youth through a mobile art gallery. Abstracts of the XVI International AIDS Conference; 2006; Toronto, Canada; 2006. Abstract no. CDC1505.

65. Kimani J, Hammond S. Capacity enhancement on documentation and learning in HIV and AIDS response for national AIDS councils in Africa: the SIPAA experience. Abstracts of the XVI International AIDS Conference; Toronto, Canada; 2006. Abstract no. CDE0528.

66. Kombe G, Decker C, Butera D, Oulai S, Chankova S, Muchiri S, et al. Emerging issues in human capacity development in low resource countries: A comparative analysis of Cote d'Ivoire, Ethiopia, Kenya, and Zambia. Abstracts of the XVI International AIDS Conference; Toronto, Canada; 2006. Abstract no. WEPE0925.

67. Legesse B, Davey G, editors. The role of indigenous practices in assisting HIV/AIDS orphans at community level in selected localities of Ethiopia. Addis Ababa, Ethiopia: Ethiopian Public Health Association; 2005.

68. Linsk N, Getu M, Goshu M. HIV treatment and care giving supports in Ethiopia. Abstracts of the XVI International AIDS Conference; Toronto, Canada; 2006. Abstract no. CDB1190.

69. Magwaza S, Anderson D, Gibbons A. Strengthening individual and institutional capacity through twinning: The Africa experience. Abstracts of the XVI International AIDS Conference; Toronto, Canada; 2006. Abstract no. THPE0947.

70. Mamo G. Peer leadership programming for HIV prevention among SNNPR police forces in Ethiopia. Abstracts of the XVI International AIDS Conference; Toronto, Canada; 2006. Abstract no. CDC1248.

71. Mammo K. Local institution capacity enhancement initiative to ensure decentralized HIV/AIDS response management. Abstracts of the XVI International AIDS Conference; Toronto, Canada; 2006. Abstract no. CDE0525.

72. Mekoyete TM. A study of management effectiveness of secondary school anti-AIDS clubs in Addis Ababa City Administration. Unpublished MA thesis, College of Education, Addis Ababa University, 2006.

73. Mengaw A. VCT as entry point for HIV prevention, care, and support. Abstracts of the XVI International AIDS Conference; Toronto, Canada; 2006. Abstract no. CDC1238.

74. Mequanent S, Tegegn A, Mamo Y. Factors affecting the initiation of antiretroviral treatment for HIV/AIDS patients in Jimma Town, southwest Ethiopia. Abstracts of the XVIth Annual Conference of the Ethiopian Public Health Association; Addis Ababa, Ethiopia; 2005. Poster presentation no. 1 .
75. Mezemir T, Burka Y, Abraham S, Ruden C. Private sector involvement for TB/HIV prevention in Ethiopia. Abstracts of the XVI International AIDS Conference; Toronto, Canada; 2006. Abstract no. TUKC204.

76. Mezemir T, Ruden C, Stratton S. Public-private collaboration: Establishing and strengthening workplace HIV/AIDS/TB services in Ethiopia. Abstracts of the XVI International AIDS Conference; Toronto, Canada; 2006. Abstract no. WEPE0484.

77. Mohamed E, Sinkineh L. HIV/AIDS mainstreaming in practise - A look at methods and processes. Abstracts of the XVI International AIDS Conference; Toronto, Canada; 2006. Abstract no. CDD1356.

78. Muhe L, Mason E, Martines J. Country experiences of integration of paediatric HIV care within child health programmes. Abstracts of the XVI International AIDS Conference; Toronto, Canada; 2006. Abstract no. WEPE0949.

79. O'Malley G, Gebre-Kidan T, Deriba Y, Linsk N. Using case managers to improve HIV/AIDS adherence in Ethiopia. Abstracts of the XVI International AIDS Conference; Toronto, Canada; 2006. Abstract no. CDB1269.

80. Pathfinder International. Ethiopia: Faith-based organizations, the key to community trust. Pathfinder International/ Ethiopia, Addis Ababa, February 2006.

81. Pathfinder International. Ethiopia: Creating Partnerships to prevent early marriage in the Amhara Region. Pathfinder International/Ethiopia, Addis Ababa, July 2006.

82. Perchal P, Collins L, Dabash R, Assefa B, Arruda S, Babenko O. Towards a rights based approach to sexual and reproductive health of HIV positive women. Abstracts of the XVI International AIDS Conference; Toronto, Canada; 2006. Abstract no. MOPE0984.

83. Qazi SA, Muhe LM. Integrating HIV management for children into the Integrated Management of Childhood Illness guidelines. Trans $\mathrm{R}$ Soc Trop Med Hyg 2006;100(1):10-13.

84. Renton L, Okello L. Capacity building in management and co-ordination of the national response: Lessons from 9 African countries. Abstracts of the XVI International AIDS Conference; 2006; Toronto, Canada; 2006. Abstract no. THPE0904.

85. Ronald K. Ethiopia in need of a "big push" to meet global targets for HIV/AIDS control. Abstracts of the XVI International AIDS Conference; Toronto, Canada; 2006. Abstract no. CDE0246.

86. Ruland R, Prugger C, Schiffer R, Regidor M, Lelle RJ. Prevalence of human papilloma virus infection in women in rural Ethiopia. Eur J Epidemiol. 2006;21(9):727-9.

87. Ruparelia C, Mahdi MA, Lulseged S, NurHussien A, Kassa A, Wyss S, et al. Innovative approaches to address barriers to scale-up of HIV/AIDS services in Ethiopia. Abstracts of the XVI International AIDS Conference; Toronto, Canada; 2006. Abstract no. CDB1099.

88. Shibru A, Ruden C, Stratton S. Raising awareness, involving men: Community mobilization for PMTCT services in Ethiopia. Abstracts of the XVI International AIDS Conference; Toronto, Canada; 2006. Abstract no. CDD0061.

89. Slater L. Community planning models: Core components and a variety of methods for mobilizing and empowering affected communities. Abstracts of the XVI International AIDS Conference; Toronto, Canada; 2006. Abstract no. 
TUPE0994.

90. Tadesse Y. Building foundation for the sustainability of injection safety in Ethiopia. Abstracts of the XVIth Annual Conference of the Ethiopian Public Health Association; Addis Ababa, Ethiopia; 2005. No abstract number.

91. Tefera Z. Determinants of youth voluntary HIV counselling and testing (VCT) acceptance in four youth centers of the family guidance association of Ethiopia (FGAE). Abstracts of the XVI International AIDS Conference; Toronto, Canada; 2006. Abstract no. CDC1184.

92. Tekleab GM. An ethnographic study on trends and communicative potentials of "Dagu" in addressing HIV/AIDS issues in the Afar Region. Unpublished MA Thesis, College of Education, Addis Ababa University; 2006.

93. Tenaw A. Care and support service provision for AIDS orphans and vulnerable children in Addis Ababa: The case of two NGOs. Unpublished MA Thesis, Department of Sociology and Social Anthropology, Addis Ababa University; 2006.

94. Tesfaye A. Mobilizing communities for the care and support of HIV/AIDS affected children and families. Abstracts of the XVI International AIDS Conference; Toronto, Canada; 2006. Abstract no. MOPDD06.

95. United Nations Higher Commissioner for Human Rights and UNAIDS. International Guidelines on HIV/AIDS and Human Rights 2006 Consolidated Version. Geneva, Switzerland: United Nations Higher Commissioner for Human Rights and UNAIDS; 2006.

96. Ward N. An International network of African organisations learning from one another to develop strong child centred community responses to HIV and AIDS. Abstracts of the XVI International AIDS Conference; Toronto, Canada; 2006. Abstract no. CDD0836.

97. Wasie KA. Creating the link: Formal and informal community care giving for AIDS orphans. Unpublished MA Thesis, School of Social Work, Addis Ababa University; 2006.

98. White K. Inakafalalen - A sharing exchange from Ethiopia: Experiences in developing holistic communitybased HIV/AIDS projects. Abstracts of the XVI International AIDS Conference; Toronto, Canada; 2006. Abstract no. CDD1486.

99. Williams BG, Korenromp EL, Gouws E, Schmid GP, Auvert B, Dye C. HIV infection, antiretroviral therapy, and CD4+ cell count distributions in African populations. J Infect Dis. 2006;194(10):1450-8.

100. Williams BG, Lloyd-Smith JO, Gouws E, Hankins C, Getz WM, Hargrove J, de Zoysa I, Dye C, Auvert B. The potential impact of male circumcision on HIV in SubSaharan Africa. PLoS Med. 2006;3(7):e262.

101. Wilson-Clark G. Mainstreaming HIV/AIDS in to the government of Ethiopia's productive safety nets programme. Abstracts of the XVI International AIDS Conference; Toronto, Canada; 2006. Abstract no. MOPE0857.

102. Wodajo ET. Awareness, culture and HIV/AIDS - The power of audiovisuals. Abstracts of the XVI International AIDS Conference; Toronto, Canada; 2006. Abstract no. CDC1758.

103. Workneh NG. Access to female condom is a reproductive health right. Abstracts of the XVI International AIDS Conference; 2006; Toronto, Canada; 2006. Abstract no.
CDE0622.

104. Wuhib T, Legesse T, Morrison L, Dempsey HF, Mereke N, Ghebreyesus TA. Global Fund-PEPFAR HIV/AIDS partnership in Ethiopia for maximal impact. Abstracts of the XVI International AIDS Conference; Toronto, Canada; 2006. Abstract no. TUPE0875.

105. Young P, Slater L, Grasso C, Jourden J, Shenie T, Negassa $\mathrm{H}$. Using an HIV/AIDS community planning model to mobilize and build a community level treatment adherence and PLWA support system. Abstracts of the XVI International AIDS Conference; Toronto, Canada; 2006. Abstract no. CDE0532.

\section{Section 7. Monitoring and Evaluation Research}

This section includes reports that focus on HIV/AIDS related program or intervention monitoring and evaluation activities.

1. Adelaja D, Stover J. Coverage and costing of HIV prevention interventions for young people: A survey of 50 countries. Abstracts of the XVI International AIDS Conference; Toronto, Canada; 2006. Abstract no. CDD1205.

2. Agdew ES. The persuasive power of HIV advertisements of Radio Ethiopia and FM Addis 97.1: A textual analysis. Unpublished MA Thesis, Department of Literature, Addis Ababa University; 2006.

3. Asfaw YD, Ruden C, Shibru A, Stratton S. Addressing provider stigma against people living with HIV/AIDS: An evaluation from Ethiopia. Abstracts of the $33^{\text {rd }}$ Annual International Conference on Global Health, Washington, DC; 2006. Panel abstract no. B1.

4. Bereded HT. Assessment of HIV/AIDS hotline counseling services in some selected organizations in Addis Ababa. Unpublished MA Thesis, College of Education, Addis Ababa University, 2006.

5. Berhane Y. Utilization of surveillance systems for guiding health interventions. Ethiop J Health Dev 2006;20(1):1-2.

6. Biru TJ. The analysis of counseling principles applications at VCT centers: The case of some selected VCT centers in Addis Ababa. Unpublished MA Thesis, College of Education, Addis Ababa University, 2006.

7. Degaga AW. Empowerment of youth club: Experience, opportunities and challenges: The case of 'Sele Tselote Egi' youth reproductive health/HIV/AIDS club in Oromia and 'Kal' RH/HIV/AIDS club in Addis Ababa Region, Ethiopia. Unpublished MA Thesis, School of Social Work, Addis Ababa University; 2006.

8. Derbew AA. Assessment of community and organizational response against the impact of HIV/AIDS in Tigray Region. Unpublished MPH, Thesis, Department of Community Health, Addis Ababa University; 2006.

9. Deribe K, Amberbir A. Outreach voluntary counseling and testing (VCT) of HIV acceptability and client satisfaction: Experience of Menschen Fur Meschen (MFM) Foundation, Illubabor Zone, southwest Ethiopia. Abstracts of the XVIth Annual Conference of the Ethiopian Public Health Association; Addis Ababa, Ethiopia; 2005. Poster presentation no. 10.

10. Desta MD. Recovery, rehabilitation and reintegration of children exposed to commercial sexual exploitation: Outcome evaluation and program analysis (The case Forum on Street Children-Ethiopia). Unpublished MA Thesis, School of Social Work, Addis Ababa University; 2006.

Ethiop.J.Health Dev. 2007;21(1) 
11. Dodi NN. Experience with HIV and infant feeding counseling tools. Abstracts of the $33^{\text {rd }}$ Annual International Conference on Global Health, Washington, DC; 2006. Panel abstract no A4.

12. Farr AC, Witte K, Jarato K, Menard T. 'The Effectiveness of Media Use in Health Education: Evaluation of an HIV/AIDS Television Campaign in Ethiopia': Erratum. J Health Communic 2005;10(7):679.

13. Farr AC, Witte K, Jarato K, Menard T. The Effectiveness of Media Use in Health Education: Evaluation of an HIV/AIDS Television Campaign in Ethiopia. J Health Communic 2005;10(3):225-235.

14. Getahun TT. An evaluation of counseling service in VCT centers in GO and NGO organizations in Dire Dawa Town. Unpublished MA Thesis, College of Education, Addis Ababa University, 2006.

15. Girma B, Lemma W, Kendall C, Santos EMd. Ethiopian and Brazil's experience in human capacity development in HIV/AIDS M\&E: Challenges and opportunities in teaching M\&E of STD/HIV/AIDS, control programs. Abstracts of the XVI International AIDS Conference; Toronto, Canada; 2006. Abstract no. THPE0941.

16. Gobeze A, Belete S, Azage T. An overview of HIV/AIDS - food security and nutrition interface and rapid assessment of the state of nutritional care and support services for PLWHA. Abstracts of the XVIth Annual Conference of the Ethiopian Public Health Association; Addis Ababa, Ethiopia; 2005. Oral presentation no. 9.

17. Godana GD. Survey of cultural appropriateness of HIV/AIDS communication: The Case of the Gumuz Community. Unpublished MA Thesis, School of Journalism and Communication, Addis Ababa University; 2006.

18. Guthrie T, Kyomuhangi LB, Kioko U, Zewdu GA, Kessey F, Sultan O, et al. Tracking HIV/AIDS resources in Africa: A multi-country project. Abstracts of the XVI International AIDS Conference; Toronto, Canada; 2006. Abstract no. THPE0993.

19. Habte D, Deyessa N, Davey G. Assessment of the utilization of pre-marital HIV testing services and determinants of VCT in Addis Ababa, 2003. Ethiop J Health Dev 2006;20(1):18-23.

20. Hailemariam A, Barker K, Barrett M, Teffera N. Results of a radio serial drama program for HIV prevention and reproductive health in Ethiopia. Abstracts of the XVI International AIDS Conference; Toronto, Canada; 2006. Abstract no. WEKC502.

21. Hailemariam TS. The significance of alternative media in HIV/AIDS communication: HIV/AIDS coverage in two mainstream newspapers and a case of alternative newspaper. Unpublished MA Thesis, School of Journalism and Communication, Addis Ababa University; 2006.

22. Kifle YG. Using VCT data as an alternative tool for trend analysis and monitoring of HIV/AIDS epidemic and its demographic impact in Addis Ababa, Ethiopia. Unpublished MSc Thesis, Department of Statistics, Addis Ababa University; 2006.

23. Lindelow $M$, Serneels $P$. The performance of health workers in Ethiopia: Results from qualitative research. Soc Sci Med 2006;62(9):2225-2235.

24. Mamo G. Review of HIV prevention peer leadership program implementation among taxi community members in Addis Ababa. Abstracts of the XVI International AIDS Conference; Toronto, Canada: Abstract no. CDC1282;
2006.

25. Mekonnen N, Daniel G, Witt H. Providing security and confidentiality for patients, ARVs, and records at ART facilities in Ethiopia. Abstracts of the XVI International AIDS Conference; Toronto, Canada; 2006. Abstract no. CDB1142.

26. Misganaw L, Etsub B. Assessment report on community based care and support project for OVC and PLWHA, in Addis Ababa, Ethiopia. Abstracts of the XVI International AIDS Conference; Toronto, Canada; 2006. Abstract no. CDD1131.

27. Nelson LJ, Stinson KW, Kim B, Miranda A, Wells CD. Challenges for collaborative tuberculosis and HIV surveillance in high prevalence settings. Abstracts of the XVI International AIDS Conference; Toronto, Canada; 2006. Abstract no. WEPE0280.

28. Oladepo O. Increasing the impact of national AIDS programme; Evidence from an independent evaluation of World Bank support. Abstracts of the XVI International AIDS Conference; 2006; Toronto, Canada; 2006. Abstract number: THPE0984.

29. Perchal P, Collins L, Assefa B, Babenko O. Costeffectiveness of integrating HIV/STI prevention interventions in maternal and child health programmes. Abstracts of the XVI International AIDS Conference; 2006; Toronto, Canada; 2006. Abstract no. TUPE0580.

30. Reniers G. HIV/AIDS surveillance and behavioral change in populations affected by the AIDS epidemic: Four essays. Unpublished $\mathrm{PhD}$ Dissertation, University of Pennsylvania; 2006.

31. Reniers G, Davy G, Araya T, Berhane Y, Sanders EJ. AIDS mortality trends following the introduction of antiretroviral treatment in Addis Ababa. Abstracts of the XVIIth Annual Conference of the Ethiopian Public Health Association; Harar, Ethiopia; 2006. Abstract no. 5.

32. Shargie EB, Morkve O, Lindtjørn B. Tuberculosis casefinding through a village outreach programme in a rural setting in southern Ethiopia: Community randomized trial. Bull World Health Organ 2006;84(2):112-9.

33. Sisay ZB. Care and support and people living with HIV and AIDS at holy water: An assessment at four selected sites in Addis Ababa. Unpublished MA Thesis, School of Social Work, Addis Ababa University; 2006.

34. Speed A, McCollum J, Phumtim G. Keeping track of obligated and incoming HIV/AIDS commodities. Abstracts of the XVI International AIDS Conference; Toronto, Canada; 2006. Abstract no. MOPE0641.

35. Stillman K, Bennett S, Kidanu A, Banteyergu H, Hounsa A, Gbangbade S, et al. How has Global Fund support interacted with national health systems in the fight against HIV/AIDS: Lessons from 3 countries. Abstracts of the XVI International AIDS Conference; Toronto, Canada; 2006. Abstract no. CDE0618.

36. Tadele G. HIV/AIDS prevention in Ethiopia: How do young people look upon intervention programmes? Abstracts of the XVI International AIDS Conference; Toronto, Canada; 2006. Abstract no. CDC1484.

37. Tafesse M, Kebede E, Kassa A, Colton T, Rabkin M, Melaku Z. Pediatric HIV/AIDS care and treatment in Ethiopia: A national situational assessment. Abstracts of the XVI International AIDS Conference; Toronto, Canada; 2006. Abstract no. CDB1098.

38. Temegen AM. Assessment of VCT utilization among attendees of FP, ANC and delivery care services, Deber 
Tabor town, Northwest Ethiopia. Unpublished MPH Thesis, Department of Community Health, Addis Ababa University; 2006.

39. Tesfaye AM. Analysis of the nature and magnitude of HIV/AIDS coverage in Ethiopian newspapers: The case of Addis Admas and Addis Zemen. Unpublished MA Thesis, School of Journalism and Communication, Addis Ababa University; 2006.

40. Tessema GB. Assessment of media use pattern in HIV/AIDS prevention among youth in Bahir Dar Town. Unpublished MPH Thesis, Department of Community Health, Addis Ababa University; 2006.

41. Tsegaye DA. Assessment of quality of voluntary HIV counseling and testing services in Addis Ababa. Unpublished MPH Thesis, Department of Community Health, Addis Ababa University; 2006.

42. Turnbull W, Chaya N. Impact of U.S. policies: Two country case studies. Abstracts of the XVI International AIDS Conference; Toronto, Canada; 2006. Abstract no. THPE0897.

43. Vitiello M, Winters D, Ouma G. Clinical mentoring experiences with Ethiopian nurses. Abstracts of the XVI International AIDS Conference; Toronto, Canada; 2006. Abstract no. WEPDB02.

44. Wakjira MK. Assessment of the process evaluation of the quality of services given by the program of secondary school anti-AIDS clubs in Southwest Shoa Zone. Unpublished MPH Thesis, Department of Community Health, Addis Ababa University; 2006.

45. Wallelu MT. Investigating the impact of media advocacy in framing accessibility of antiretroviral treatment in Ethiopia: A social work perspective. Unpublished MA Thesis, School of Social Work, Addis Ababa University; 2006.

46. Wirth ME, Balk D, Delamonica E, Storeygard A, Sacks E, Minujin A. Setting the stage for equity-sensitive monitoring of the maternal and child health Millennium Development Goals. Bull World Health Organ 2006;84(7): 519-527.

47. Woldegiorgis MW. Status survey of voluntary counseling test and posttest services provided by Mojo Municipality HIV/AIDS Committee in Collaboration with Save the Children USA. Unpublished MA Thesis, College of Education, Addis Ababa University, 2006.

48. Wondwossen D. HIV counseling and testing (VCT) for preschool and school aged children: Experience at hospital based pediatric VCT site, Ethiopia, East Africa. Abstracts of the XVI International AIDS Conference; Toronto, Canada; 2006. Abstract no. WEPE0427.

49. Yassin MA, Datiko DG, Shargie EB. Ten-year experiences of the tuberculosis control programme in the southern region of Ethiopia. Int $J$ Tuberc Lung Dis 2006;10(10):1166-71.

50. Yaszi DT. Review and evaluation of the care and support programs of Mekdim Ethiopia National Association of Persons Living with HIV/AIDS and their Family. Unpublished MA Thesis, School of Social Work, Addis Ababa University; 2006.

\section{Section 8. HIV/AIDS Research on Ethiopians in the Diaspora}

This section covers HIV/AIDS among Ethiopians and foreign residents of Ethiopian origin living outside of Ethiopia. It includes basic science, epidemiology, intervention, clinical, impact and social issues research.

1. Abebe Y, Doherty M, Dawd S, Getachew A, Bartlett JG. Increased transfer of knowledge through HIV/AIDS telemedicine case conference: Addis Ababa, Ethiopia. Abstracts of the XVI International AIDS Conference; Toronto, Canada; 2006. Abstract no. WEPE0101.

2. Achonu C, Gournis E, Ackery J-A, Yaffe B, Shahin R. Changing demographic trends in Toronto's HIV population, 1994 to 2004. Abstracts of the XVI International AIDS Conference; Toronto, Canada; 2006. Abstract no. CDC0357.

3. Asfaw D, Jorgensen S. Is HIV/AIDS the gamble girls must take in order to survive? The roles of Ethio-American men in persuading the sexual risk-taking behaviors of adolescent girls in Gondar town of Ethiopia. Abstracts of the XVI International AIDS Conference; Toronto, Canada; 2006. Abstract no. CDD0275.

4. Bentwich Z. Helminthic infections have a major impact on the pathogenesis and vaccination against HIV infection: Should we deworm the populations? Abstracts of the XVI International AIDS Conference; Toronto, Canada; 2006. Abstract no. TUPE0016.

5. Chemtob D, Weiler-Ravell D, Leventhal A, Bibi H. Epidemiologic characteristics of pediatric active tuberculosis among immigrants from high to low tuberculosis-endemic countries: the Israeli experience. Isr Med Assoc J 2006;8(1):21-26.

6. Clifford DB. Introducing "People to People": Meet Dawn McGuire, MD. Horn Africa J AIDS 2005;2(2):5-6.

7. Clifford DB. Introducing "People to People" featuring Davis B. Clifford, MD. Horn of Africa J AIDS 2005;2(1):5.

8. Constantinos BT. The potential within: Is the Ethiopian Diaspora a response to the nation's brain drain? Excerpts from the final report. Horn Africa J AIDS 2005;2(2):6272.

9. Elchalal U, Goslitzer T, Eisenberg V, Arbel R, Maayan S. Mother to child transmission of HIV among Ethiopian immigrants before and after immigration - The Jerusalem Experience. J Soc Gynecol Investig 2006;13(2):347A.

10. Fenta H, Alemayehu E, Noh S. Sexual risk-taking behaviour of Ethiopian immigrants in North America. Horn Africa J AIDS 2006;3(1):30-40.

11. Gardezi F, Calzavara L, Lawson E, Husbands W, Tharao E, Willms D, et al. Racism and HIV/AIDS: Impacts of racialized discourse on the daily lives of African and Caribbean communities in Toronto, Canada. Abstracts of the XVI International AIDS Conference; Toronto, Canada; 2006. Abstract no. WEAD0102.

12. Giorgis TW. Second strengthening the ties with the Ethiopian Diaspora to fight HIV/AIDS. Abstracts of the Meeting Organized by the Network of Ethiopian Professionals in the Diaspora and the Twinning Center; Los Angeles, CA; 2006.

13. Gottesman BS, Grossman Z, Lorber M, Levi I, Shitrit P, Katzir M, Shahar E, Gottesman G, Chowers M. Comparative performance of the Amplicor HIV-1 Monitor Assay versus NucliSens EasyQ in HIV subtype C-infected patients. J Med Virol. 2006;78(7):883-7.

14. Gray K, Calzavara L, Tharao E, Burchell A, Myers T, Remis R, et al. Perception of risk, risk behaviour and sexual networks among immigrant east African communities living in Toronto, Canada. Abstracts of the 
XVI International AIDS Conference; Toronto, Canada; 2006. Abstract no. MOPE0377.

15. Lawson E, Calzavara L, Gardezi F, Husbands W, Tharao E, Willms D, et al. African and Caribbean perspectives on HIV/AIDS etiology and prevention: Theoretical implications. Abstracts of the XVI International AIDS Conference; Toronto, Canada; 2006. Abstract no. MOPE0731.

16. Leng Q, Bentwich Z, Borkow G. Increased TGF-beta, Cbl$\mathrm{b}$ and CTLA-4 levels and immunosuppression in association with chronic immune activation. Int Immunol. 2006;18(5):637-44.

17. Mucheri J. Building the capacity of refugees to manage HIV/AIDS prevention interventions in Somaliland. Abstracts of the XVI International AIDS Conference; 2006; Toronto, Canada; 2006. Abstract number: THPE0501.

18. Olshtain-Pops K, Goslitzer T, Ibrahim S, Hauzi M, Maayan S. Cholesterol and triglyceride response upon exposure to ART among Ethiopian and non-Ethiopian patients at the Hadassah AIDS center in Israel. Abstracts of the XVI International AIDS Conference; Toronto, Canada; 2006. Abstract no. CDB0657.

19. Papo J, Burns L. The impact of HIV/AIDS on refugees mortality trends in Dukwi refugee camp, Botswana. Abstracts of the XVI International AIDS Conference; Toronto, Canada; 2006. Abstract no. MOPE0299.

20. Stein-Zamir C, Volovik I, Rishpon S, Atamna A, Lavy A, Weiler-Ravell D. Tuberculosis outbreak among students in a boarding school. Eur Respir J. 2006;28(5):986-91.

21. Wyatt CM, Klotman PE. HIV-associated nephropathy: A case study in race and genetics. Am J Kidney Dis 2006;47(6):1084-5.

\section{Section 9. Selected Websites Featuring HIV/AIDS in Ethiopia}

1. Center for International Health of the University of Bergen, Norway (also access to the Ethiopian Journal of Health Development): http://www.cih.uib. no/journals/EJHD

2. Christian Relief and Development Association: www.crdaethiopia.org

3. Ethiopian AIDS Resources Center: http://www. etharc.org

4. Family Health International: http://www.fhi.org/en/ CountrProfiles/Ethiopia+main+page.htm

5. Johns Hopkins University Center for Clinical Global Health Education: http://ccghe.jhmi.edu/CCG/ country/ethiopia/

6. People to People Organization: http://peoplepeople. org/; its Horn of Africa Journal of AIDS is available at: http://peoplepeople.org/index.php?P=47

7. Save the Children: http://www.savethechildren.net/ ethiopia/key_issues/abuse.html

8. United Nations Children's Fund (UNICEF): http://www.unicef.org/ethiopia/hiv_aids_464.html

9. United Nations Development Programme (UNDP): http://www.et.undp.org/hiv/hiv.htm

10. United Nations Educational, Scientific and Cultural Organization (UNESCO): http://hivaidsclearinghouse.unesco.org/ev_en.php?ID=282 9_201\&ID2=DO_TOPIC

11. United Nations Joint Program on AIDS (UNAIDS): http://www.unaids.org/en/Regions_Countries/Countries/et hiopia.asp

12. United States Centers for Disease Control and Prevention (CDC): http://www.cdc.gov/nchstp/od/ 